\title{
How Can Decision Support Tools Help Reduce Nitrate and Pesticide Pollution from Agriculture? A Literature Review and Practical Insights from the EU FAIRWAY Project
}

\author{
Fiona Nicholson ${ }^{1, *}$, Rikke Krogshave Laursen ${ }^{2}$, Rachel Cassidy ${ }^{3}$, Luke Farrow ${ }^{3}$, \\ Linda Tendler ${ }^{4}$, John Williams ${ }^{5}$, Nicolas Surdyk ${ }^{6}$ and Gerard Velthof ${ }^{7}$ (D) \\ 1 ADAS Gleadthorpe, Meden Vale, Mansfield, Nottinghamshire NG20 9PD, UK \\ 2 Danish Agriculture \& Food Council F.m.b.A., SEGES, Agro Food Park 15, 8200 Aarhus N, Denmark; \\ RILA@seges.dk \\ 3 Agri-Environment Branch, Agri-Food and Bioscience Institute (AFBI), Newforge Lane, Belfast BT9 5PX, \\ Northern Ireland, UK; rachel.cassidy@afbini.gov.uk (R.C.); luke.farrow@afbini.gov.uk (L.F.) \\ 4 Chamber of Agriculture of the Federal State of Lower Saxony, Helene-Künne-Allee 5, 38122 Braunschweig, \\ Germany; linda.tendler@lwk-niedersachsen.de \\ 5 ADAS Boxworth, Battlegate Road, Boxworth, Cambridge CB23 4NN, UK; john.williams@adas.co.uk \\ 6 Bureau de Recherches Geologiques et Minieres (BRGM), 3 avenue Claude Guillemin, BP 36009, CEDEX 2, \\ 45060 Orleans, France; n.surdyk@brgm.fr \\ 7 Wageningen Environmental Research, Droevendaalsesteeg 3, 67808 PB Wageningen, The Netherlands; \\ gerard.velthof@wur.nl \\ * Correspondence: fiona.nicholson@adas.co.uk
}

Received: 30 January 2020; Accepted: 4 March 2020; Published: 11 March 2020

check for updates

\begin{abstract}
The FAIRWAY project reviewed approaches for protecting drinking water from nitrate and pesticide pollution. A comprehensive assessment of decision support tools (DSTs) used by farmers, advisors, water managers and policy makers across the European Union as an aid to meeting CAP objectives and targets was undertaken, encompassing paper-based guidelines, farm-level and catchment level software, and complex research models. More than 150 DSTs were identified, with 36 ranked for further investigation based on how widely they were used and/or their potential relevance to the FAIRWAY case studies. Of those, most were farm management tools promoting smart nutrient/pesticide use, with only three explicitly considering the impact of mitigation methods on water quality. Following demonstration and evaluation, 12 DSTs were selected for practical testing at nine diverse case study sites, based on their pertinence to local challenges and scales of interest. Barriers to DST exchange between member states were identified and information was collected about user requirements and attitudes. Key obstacles to exchange include differences in legislation, advisory frameworks, country-specific data and calibration requirements, geo-climate and issues around language. Notably, DSTs from different countries using the same input data sometimes delivered very different results. Whilst many countries have developed DSTs to address similar problems, all case study participants were able to draw inspiration from elsewhere. The support and advice provided by skilled advisors was highly valued, empowering end users to most effectively use DST outputs.
\end{abstract}

Keywords: DST; software; model; drinking water; diffuse pollution; catchment management; farm management; farm advisors 


\section{Introduction}

Safe drinking water is vital for public welfare and is an important driver of a healthy economy. The productivity of agriculture in the EU has greatly increased over recent decades, in part through the increased availability of fertilisers and pesticides, which have boosted crop and animal production. However, the increased inputs of fertilisers (both mineral and organic) and pesticides to agricultural soils have also led to increased losses to the environment, thereby contributing to the pollution of ground and surface drinking water sources.

To deal with this pollution, the EU has developed an extensive set of directives, guidelines and policies. The requirements of the Drinking Water Directive set an overall minimum quality for drinking water within the EU. In addition, the Water Framework Directive, the Groundwater Directive, the Nitrates Directive and the Directive on the Sustainable Use of Pesticides require member states (MS) to protect water resources against pollution in order to ensure the safety of drinking water. While many improvements have been achieved [1], the directives are not achieving a consistent level of implementation and effectiveness across all MS. As a consequence, limits for nitrate $(50 \mathrm{mg} / \mathrm{L})$ and pesticides $(0.1 \mu \mathrm{g} / \mathrm{L})$ in groundwater and surface water are still exceeded in many MS [2]. Whilst easy, low cost measures for tackling pollution sources and pathways have been successful, as they become exhausted, further improvements in water quality will require innovative solutions and more targeted mitigation measures if agricultural productivity is not to be affected.

The need for technology in developing bespoke management approaches and decision support for users has been highlighted as a core element of the Common Agricultural Policy (CAP) proposals for 2021-27, and as key to meeting CAP objectives and targets in the future [3]. In their CAP Strategic Plan, MS will have to outline how they will stimulate knowledge exchange and innovation covering aspects, such as farm advisory services and training [4] and encourage the use of big data and new technologies for control and monitoring [5].

There have been many decision support tools (DSTs) developed in the EU and elsewhere to assist end users to make more effective decisions on how to minimise contaminant losses to water, and hence to protect and improve drinking water quality. The target audience of these DSTs ranges widely. At one end are water managers and policy makers who work at the catchment or national scale to set water quality targets and monitor the effectiveness of mitigation measures. At the other end are individual farmers and advisors who may use DSTs to provide guidance on farm management practices (e.g., product choice; timing of pesticide, manure and fertiliser applications) which could have a direct or indirect impact on water quality. DSTs may either lead end users through clear decision stages and present them with the likelihood of various outcomes (social or/and economic) occurring, or they can encourage users to optimise (minimise) their use of e.g., manufactured fertiliser nitrogen $(\mathrm{N})$ and pesticides with respect to a legal framework. Policy makers may also simulate the impacts of excluding harmful substances, specifying usage limits or changing the taxation regime. DSTs may be paper based systems (e.g., fertiliser recommendations) or dynamic software tools, whose recommendations vary according to the user's inputs, and they may suggest an optimal decision path [6]. However, the extent to which DST are transferrable across MS has not been assessed to date and is an impediment to achieving the technological and DST requirements of the CAP going forward.

The EU Horizon 2020 funded "Farm systems that produce good water quality for drinking water supplies (FAIRWAY)" project was established in 2017 to review current approaches and measures for the protection of drinking water resources against pollution caused by pesticides and nitrate from agriculture in the EU, and to identify and develop innovative approaches to more effective drinking water protection [7]. One of the specific project objectives was to review, demonstrate and evaluate DSTs offering advice, training and communication related to the protection of drinking water quality (either directly or indirectly) for a range of end users. As part of the project, 13 case study areas were identified in 10 MS covering different types of drinking water supplies (groundwater and surface water), pedo-climatic zones, type of farming, land use, legal framework and governance (Figure 1). The case studies provided the project with a means to directly contact farmers and other stakeholders. 
They also offered a way to establish which DSTs and mitigation measures were being used in practice to safeguard drinking water resources, and acted as a forum for evaluating DSTs, to establish whether there was potential for DST exchange between countries.

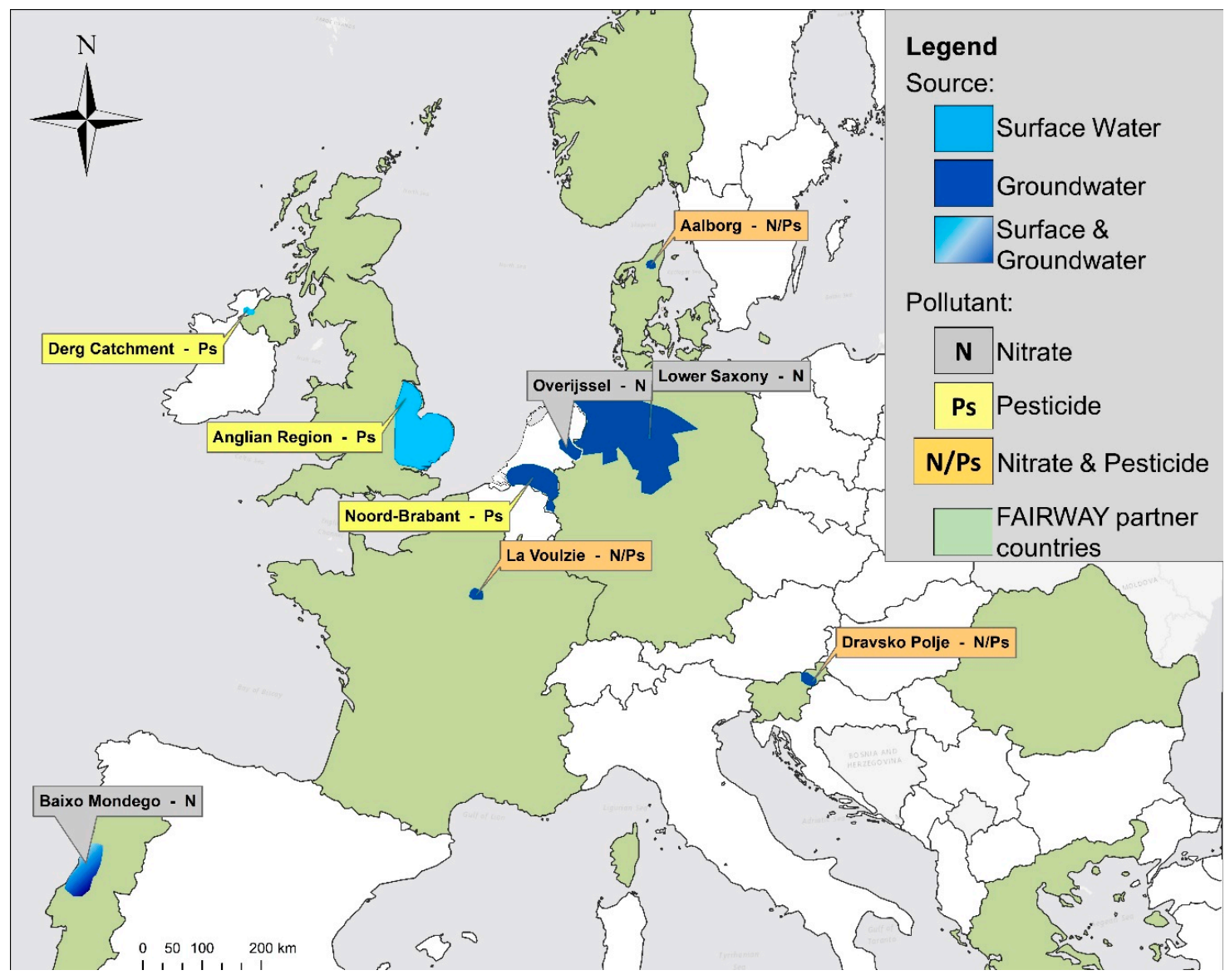

Figure 1. Location and overview of the 9 FAIRWAY case study sites involved in the DST evaluation, including the drinking water source, case study size and the main pollutant(s) of concern.

The objective of this study was therefore to systematically review the literature to identify DSTs that could help to establish awareness of diffuse nitrate and pesticide pollution of vulnerable drinking water resources and/or improve on-farm management practices to protect water quality. The review considered DSTs operating at different scales (e.g., software tools used by individual farmers or advisors; catchment scale policy tools; paper based recommendations), with a different focus (i.e., those dealing with either nitrogen or pesticide management, or both) and which were relevant to protecting the quality of different drinking water sources (i.e., ground water or surface water systems). DSTs dealing solely with phosphorus $(\mathrm{P})$ management were not considered as P concentrations in drinking water are not currently regulated. A subset of the DSTs were selected for demonstration and/or implementation at 9 of the 13 FAIRWAY case study sites to evaluate the potential benefits/opportunities of DST transfer between countries, identify any barriers to exchange and assess stakeholder perception.

\section{Methodology}

A summary of the different stages of the review, selection and testing of the DSTs in the FAIRWAY case studies is given in Figure 2, and described in more detail below. 


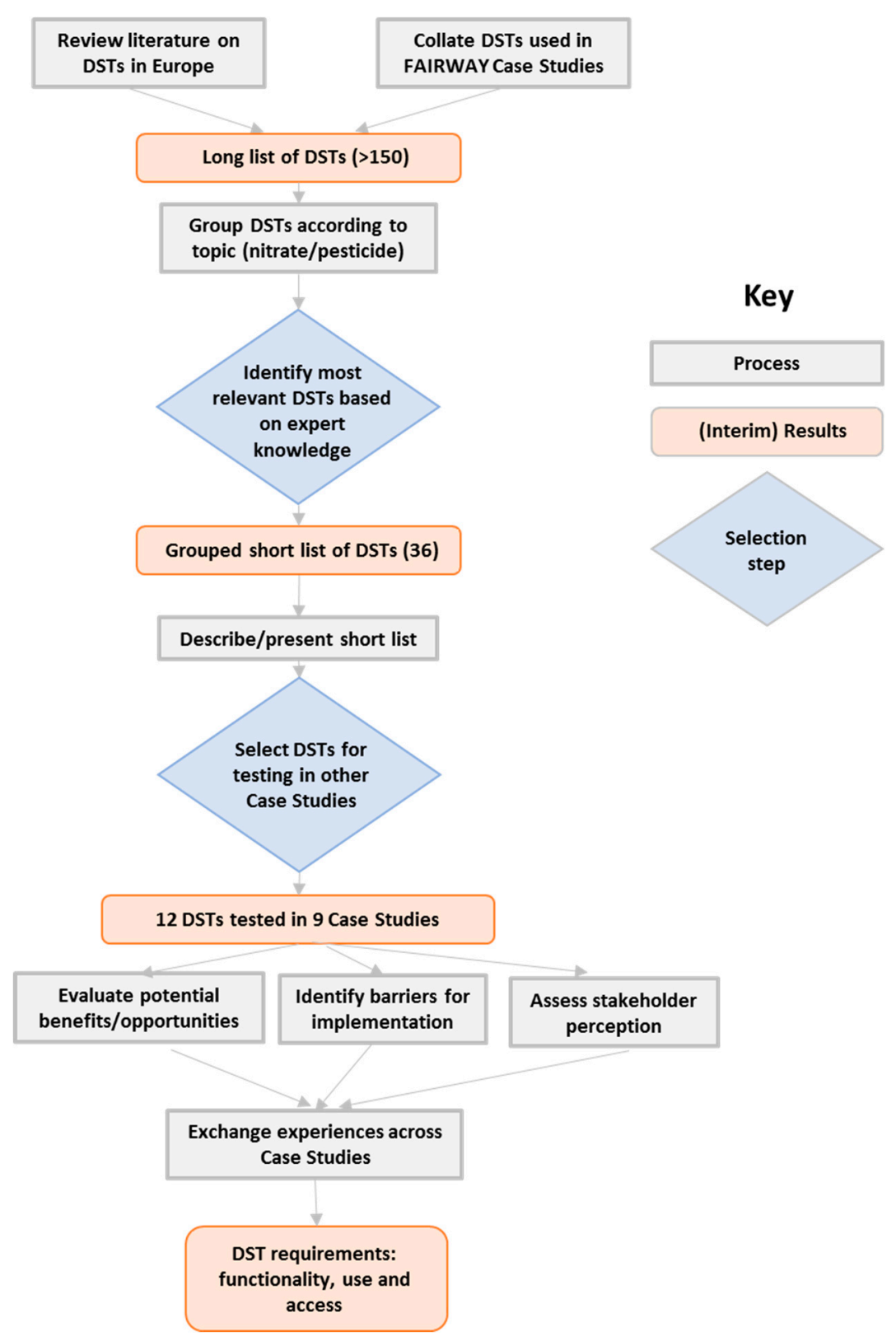

Figure 2. Flowchart showing the stages of the review, selection and testing of DSTs in the FAIRWAY case studies.

\subsection{Definitions and Scope}

For the purposes of this review, a DST was defined as any bespoke (i.e., custom-made) or generic (i.e., 'off the shelf') software, email/text alerts, online calculator or guidance, phone app, and paper-based guidance that could contribute to an end user decision affecting surface or ground water quality. The definition does not include 'human-based' DSTs, such as advisors or peers. In addition, the DST must have been in practical operation (i.e., in active use) or released by the end of 2017. The DSTs considered were those used by the FAIRWAY project partners and elsewhere in Europe (including Norway, Switzerland and other non-EU countries with similar agroclimatic conditions) on farms and within single catchments, groundwater abstraction areas, regions, countries or larger areas. Demonstration versions of DST's were included if they were functional, had been tested on end-users and were assessed to have a potential for practical use. End users were defined as:

- Farmers 
- Agronomists and other farm advisors

- Water quality managers

- Policy makers

- Fertiliser or pesticide manufacturers or suppliers

- $\quad$ Researchers

Water quality was defined in terms of:

- $\quad \mathrm{N}$ concentrations in the form of total $\mathrm{N}$ and/or nitrate and/or ammonium and/or nitrite.

- Pesticide concentrations, where pesticides are defined as any insecticide, herbicide, fungicide, nematicide, acaricide, slimicide, molluscicide and any product related to any of these including any growth regulator, and their relevant metabolites, degradation and reaction products. Relevant was taken to mean any metabolites, degradation and reaction products that have similar properties to their parent pesticides [8]. The pesticides included were those in current professional use in agriculture in the different countries.

The focus of the review was on DSTs operating at farm, regional or national scale that could be of practical use in reducing $\mathrm{N}$ or pesticide pollution in the FAIRWAY project case study areas.

\subsection{Identification of Relevant DSTs}

The compilation of an initial list of relevant DSTs currently in use was approached in two ways. Firstly, DSTs meeting the definitions given above were identified by undertaking a search of the published scientific literature using the Web of Science Core Collection (1994-2017). The keywords used for the search were discussed and agreed with all task participants, and are listed in Table A1. In addition, each FAIRWAY project participant supplied a list of relevant DSTs used in their respective case studies (Denmark, Germany, France, The Netherlands, Norway, Portugal, Slovenia, England and Northern Ireland), informed by the appropriate national experts. Information for the Republic of Ireland, which is not a FAIRWAY participant country, was supplied by the project partner from Northern Ireland as the case study area is a transboundary river catchment on the Irish border covering both jurisdictions.

The information supplied for each DST is detailed in Table A2, and was collated as a series of 'information capture proformas' in a spreadsheet-based database. Note that information about a DST did not need to have been published in the scientific literature to be included in the database. If documentation was available only in a national language (i.e., not English) then the participants supplied a written summary of the DST in the spreadsheet database.

The DSTs identified in the literature search and by the FAIRWAY project partners were combined into a 'long list'. An assessment was made of the search comprehensiveness by circulating this list to the FAIRWAY project partners, who were then able to identify whether any key DSTs had been omitted and add them to the list as appropriate. The FAIRWAY project partners also confirmed whether the DSTs on the 'long list' were in active use (see Definitions and Scope).

Once the database was complete, the DSTs were grouped according to their broad topic area (i.e., whether they dealt with $\mathrm{N}$ or pesticides or both), and the primary users and scale of operation were identified. Recognising that it would not be possible within the framework of the FAIRWAY project to study all the DSTs in depth, the project partners identified (based on their expert knowledge and experience) a 'shortlist' of 3-5 DSTs from their country which they assessed to be the most widely used and/or of most potential relevance in the FAIRWAY case studies. Key information used in the selection process included the:

- $\quad$ number and type of users;

- $\quad$ suitability for use across multiple MS;

- level of complexity;

- $\quad$ ability to meet the needs of actors in the FAIRWAY case study areas. 
A series of 3-page 'information sheets' was produced, summarising relevant technical and practical aspects of the shortlisted DSTs, which the FAIRWAY participants had previously agreed should be captured (Table A2). These were made available to the researchers who were leading the FAIRWAY work in the case studies and other project participants. In addition, a classification scheme was devised to better understand the target users of the DSTs and the types of support they were intended to provide.

\subsection{Selection, Implementation and Evaluation of DSTs in the Case Studies}

Nine of the FAIRWAY case study sites located across the EU (Figure 1) were involved in the evaluation of the DSTs. The case study sites were asked to re-evaluate the shortlisted DSTs (Table A3) and to identify a subset of 1-3 DSTs for testing and/or demonstration. Consideration was given to any barriers for transferring the DST into a new context (e.g., language issues, lack of support/documentation, data availability, specialist skills required, cost) and whether similar DSTs were already available in the country.

Once the selections had been made, bilateral contact with the owners of the DSTs was established and access to the software obtained. An evaluation scheme was designed to help the case study leaders assess the selected DSTs further with regard to scale, data requirements, level of experience/training required, stakeholders etc. Following the pre-testing phase (i.e., the case study site could obtain access to the DST, get support/documentation from the DST owner and provide the required input data), the testing and evaluation of DST outputs commenced. In many case study sites, this also included demonstration of the DST to relevant stakeholders and application of the DST using local data. In the final phase, the participating case study sites evaluated whether it would be possible to implement the DSTs (or parts of the DST) in their country or context, based on the test results and findings. Key objectives of the evaluation of the DSTs in the case studies related to i) evaluating the potential benefits/opportunities presented ii) identifying any barriers to implementation and iii) assessing stakeholder perception.

\section{Results and Discussion}

\subsection{General Remarks}

The term 'decision support tool' and its synonyms (Table A1), when entered into a search engine, returns a large number of 'hits'. This is because it can be applied to a wide range of tools encompassing paper-based guidelines, bespoke software and phone apps used by farmers, as well as complex sets of mathematical models intended for modelling and research purposes. All can justifiably claim to aid decision making, albeit for different sets of end users.

We found that the scientific literature searches returned significantly different numbers of 'hits' depending on the intended primary users: papers on DSTs developed for modelling and research purposes have been actively published, whilst only a limited number of papers on tools used by farmers and advisors were found in peer-reviewed journals. By their very nature these tend to be more practical tools intended for routine farm use. They may be based on sound scientific principles, but scientific publications may not necessarily be their main focus. Information on this type of DST is more likely to be made available by the developers or funders (e.g., national government, extension service; fertiliser/pesticide manufacturers) in the form of user guides or other web-based information, and is often only available in the local language. Hence, it was extremely valuable to access the information supplied by the FAIRWAY project partners about the DSTs most widely used in their countries, as these included farm-based tools not captured by the literature searches.

The complexity and competitiveness of the pesticide market can mean that chemical companies will develop product-specific DSTs and will only make these available to users of their product(s); these DSTs are unlikely to appear in the scientific literature and there is limited publicly available information about them. Nevertheless, because of the commercial power of these companies these DSTs can be very 
popular and widely used. More general pesticide management tools are fewer in number and have usually been developed by academics (e.g., Environmental Yardstick for Pesticides [9]; FarmHedge [10]) to cover a wider range of plant protection products. For example, the Dutch DST Environmental Yardstick for Pesticides [9] offers comparison of 3 crop protection products for free and comparison of an 'unlimited' number on purchase of a subscription.

Many of the DSTs identified in the literature review as tools for $\mathrm{N}$ management (i.e., providing $\mathrm{N}$ recommendations for optimal crop yield) also deal with the management of other nutrients such as $\mathrm{P}$, therefore these are henceforward referred to under the general term 'nutrient management' DSTs. A number of the nutrient management DSTs identified in this report were also commercial software tools only available at a charge to the end user (e.g. Mark Online [11], Plant Protection Online [12]). In some cases, these DSTs were developed by or in conjunction with academic institutions (e.g., NDICEA [13]); in others, the details of DST development, validation and testing are commercially sensitive and are not publicly available. In the UK, the computer code for nutrient management DSTs such as PLANET [14] and MANNER [15], which were developed using public funding from Defra (the government Department of Environment, Food and Rural Affairs), has now been made freely available and is incorporated with widely-used commercial software tools for farmers; these DSTs are also compatible with advisory information published online as the Nutrient Management Guide (RB209) [16].

Some of the DSTs were either meteorological information services (Agro-Meteorological Service [17]) providing information and advice on when weather conditions are likely to be suitable for pesticide application (and other agricultural operations), or the DST included access to meteorological information (e.g., Plant Protection Online [12]), often via a phone app interface (e.g., FarmHedge [10]), making them suitable for farmers to use in the field.

Table A3 also shows that most of the shortlisted tools were developed in NW Europe, probably reflecting the relative wealth of this region, the availability of funding and investment, and the level of relevant knowledge and expertise.

\subsection{Types of DST}

Table A3 shows the shortlist of 36 DSTs selected by the FAIRWAY project partners for further consideration and potential practical evaluation in the case studies. Only a few of the selected DSTs addressed both nutrient and pesticide management (Mark Online [11] and Dyrkningsvejledninger [18]; Bodemconditiescore [19]). Mark Online is the most widely used farm information management system in Denmark and covers all aspects of crop management including soil tillage and crop protection [11], whilst another Danish tool, Dyrkningsvejledninger [18], consists of manuals for growing different crops which provide information on Good Agricultural Practice and crop protection. Bodemconditiescore, widely used by dairy farmers in the Netherlands, is a visual evaluation method for grassland, which indicates soil quality problems and provides advice on pest population dynamics [19]. In the UK, widely used commercial farm advice tools, although not on the shortlist in Table A3, often include modules for both nutrient and pesticide planning and management, so that farmers only need to purchase a single software package to cover all their requirements.

The DST classification schemes (Tables 1 and 2) allowed the nutrient and pesticide management DSTs to be separated into those developed to support water quality/agri-environment policy makers operating at a regional or national level, and those intended to support sustainable $\mathrm{N}$ management at the farm level. The DSTs were further divided into groups depending on whether they provided support for:

- $\quad$ evaluation of current practices;

- strategic advice for farm management and implementation of nitrate/pesticide mitigation measures;

- on-farm operational management. 
Table 1. Classification scheme for nutrient management DSTs (numbers in brackets refer to the DST number in Table A1).

\begin{tabular}{|c|c|c|c|}
\hline & \multicolumn{3}{|c|}{ Provides Support For: } \\
\hline Purpose & $\begin{array}{c}\text { Evaluation Current } \\
\text { Practices }\end{array}$ & $\begin{array}{c}\text { Strategic Advice, Farm } \\
\text { Management and } \\
\text { Implementation of Measures }\end{array}$ & $\begin{array}{l}\text { Operational } \\
\text { Management }\end{array}$ \\
\hline $\begin{array}{l}\text { To support regional } \\
\text { (water quality, } \\
\text { agri-environment) } \\
\text { policy makers }\end{array}$ & $\begin{array}{l}\text { (6) CTtools } \\
\text { (7) BEST Kemi } \\
\text { (20) STONE } \\
\text { (21) CLMN } \\
\text { (26) OENBAL } \\
\text { (27) GROWA-SI } \\
\text { (28) SNGMP } \\
\text { (31) FARMSCOPER } \\
\text { (35) SCIMAP }\end{array}$ & $\begin{array}{c}\text { (8) TargetEconN } \\
\text { (20) STONE } \\
\text { (21) CLMN } \\
\text { (26) OENBAL } \\
\text { (31) FARMSCOPER }\end{array}$ & \\
\hline $\begin{array}{c}\text { To support } \\
\text { sustainable farm } \\
\text { nutrient } \\
\text { management }\end{array}$ & $\begin{array}{l}\text { (1) Düngeplanung } \\
\text { (2) ISIP } \\
\text { (3) Mark Online } \\
\text { (13) ANCA } \\
\text { (16) BWW } \\
\text { (17) Bodemconditiescore } \\
\text { (25) SSG }\end{array}$ & $\begin{array}{c}\text { (1) Düngeplanung } \\
\text { (2) ISIP } \\
\text { (3) Mark Online } \\
\text { (4) Dyrkningsvejledninger } \\
\text { (11) Teagasc NMP Online } \\
\text { (13) ANCA } \\
\text { (16) BWW } \\
\text { (24) Načrtovanje Gnojenja } \\
\text { (25) SSG } \\
\text { (30) PLANET/MANNER }\end{array}$ & $\begin{array}{l}\text { (12) Farmhedge } \\
\text { (14) CBGV } \\
\text { (15) BeregeningsWijzer } \\
\text { (18) NDICEA } \\
\text { (22) Skifteplan } \\
\text { (30) PLANET/MANNER }\end{array}$ \\
\hline
\end{tabular}

Table 2. Classification scheme for pesticide management DSTs (numbers in brackets refer to the DST number in Table A1).

\begin{tabular}{|c|c|c|c|}
\hline & & Provides Support for: & \\
\hline Purpose & $\begin{array}{c}\text { Evaluation of Current } \\
\text { Practices }\end{array}$ & $\begin{array}{l}\text { Strategic Advice on Farm } \\
\text { Management and } \\
\text { Implementation of } \\
\text { Measures }\end{array}$ & Operational Management \\
\hline $\begin{array}{l}\text { To support regional } \\
\text { (water quality, } \\
\text { agri-environment) policy } \\
\text { makers }\end{array}$ & $\begin{array}{l}\text { (7) BEST Kemi } \\
\text { (9) Phytopixal } \\
\text { (10) SIRIS } \\
\text { (19) Yardstick } \\
\text { (28) SNGMP }\end{array}$ & $\begin{array}{l}\text { (9) Phytopixal } \\
\text { (10) SIRIS } \\
\text { (29) FITO-INFO }\end{array}$ & \\
\hline $\begin{array}{l}\text { To support sustainable } \\
\text { farm pesticide } \\
\text { management }\end{array}$ & $\begin{array}{c}\text { (3) Mark Online } \\
\text { (9) Phytopixal } \\
\text { (10) SIRIS } \\
\text { (17) Bodemconditiescore } \\
\text { (19) Yardstick } \\
\text { (29) FITO-INFO }\end{array}$ & $\begin{array}{l}\text { (3) Mark Online } \\
\text { (4) Dyrkningsvejledninger } \\
\text { (5) Plant Protection Online } \\
\text { (19) Yardstick }\end{array}$ & $\begin{array}{l}\text { (5) Plant Protection Online } \\
\text { (12) FarmHedge } \\
\text { (32) Check it Out } \\
\text { (33) Sentinel Online } \\
\text { (34) Procheck. } \\
\text { (36) WaterAware }\end{array}$ \\
\hline
\end{tabular}

Very few of the selected DST were aimed explicitly at improving water quality or represented water quality directly (e.g., by the calculation of $\mathrm{N}$ or pesticide concentrations); Table A3. Many are agronomic tools for farmers and advisors which aim to optimise the use of $\mathrm{N}$ and/or pesticides to obtain maximum crop yields. They are effectively farm management tools and their inclusion in this review was based on the assumption that the efficient use of $\mathrm{N}$ and pesticides will improve water quality.

Using a fertiliser recommendation system or a manure management tool will facilitate the application of the correct amount of fertiliser/manure to meet crop needs at the appropriate time, thus minimising nutrient losses to water bodies. Most project participants reported using this type of DST. For example, Düngeplanung, which is used in Lower Saxony (Germany), was specifically developed to help farmers in water sensitive areas (e.g., for drinking water abstraction) with fertiliser planning and regulatory compliance [20]. Supported by water suppliers, it indirectly affects water quality by: 
- combining all the available information for a farm (soil analyses, crop rotation, fertiliser history, specific restrictions in water protected areas);

- optimising yields and thus the amount of $\mathrm{N}$ exported from the field;

- improving N-efficiency;

- providing practical information on amounts and timing of fertiliser applications.

Farmers using Düngeplanung have reported reductions in fertiliser use of roughly 5-10\% (L. Tendler, personal communication) Whilst again not specifically designed to represent water quality, the French SIRIS tool allows pesticides to be classified according to their potential to reach surface and ground water, and helps to organize the monitoring of pesticides in waters at the regional or local scale [21].

\subsection{Representation of Mitigation Methods}

Only three of the shortlisted DSTs were explicitly developed to consider the impact of mitigation methods on water quality: FARMSCOPER, Environmental Yardstick for Pesticides and Catchment Lake Modelling Network (Table A3).

FARMSCOPER, first developed in 2010, is a DST that can be used to assess diffuse agricultural pollutant loads (including nitrate, $\mathrm{P}$, pesticides and sediment) on a farm and quantify the impacts of farm mitigation methods on these pollutants [22]. Inputs are at the farm scale, however the outputs can be scaled up to catchment, regional and national levels. It currently contains over 100 mitigation methods, adapted from the User Guide for England and Wales [23], and they can be tested either individually or in combination for 3 broad soil types, defined according to the probability of having artificial under-drainage for conventional agriculture: (i) not requiring under-drainage; (ii) requiring under-drainage for arable use; and (iii) requiring under-drainage for both arable and grassland. The testable mitigation methods relating to nitrate and pesticide management include:

- Establish cover crops in the autumn;

- Establish riparian buffer strips;

- Extend/reduce grazing season;

- Cultivate land for crops in spring not autumn;

- Cultivate and drill across the slope;

- Early harvesting and establishment of crops in the autumn;

- Do not apply manufactured fertiliser to high-risk areas;

- Calibration of sprayer;

- Fill/mix/clean sprayer in field;

- Avoid plant protection product (PPP) application at high risk timings;

- Drift reduction methods;

- PPP substitution;

- Construct bunded impermeable PPP filling/mixing/cleaning area;

- Treatment of PPP washings through disposal, activated carbon or biobeds.

FARMSCOPER [22] is used primarily by policy makers, scientists and catchment managers, with the potential to be used by advisors on farms. To date, it has been used to study the impacts of various mitigation methods in the Wensum and Avon Demonstration Test Catchments (DTCs) in England [24] and more recently to evaluate the potential economic and environmental impacts of new and revised mitigation measures for nutrient and sediment mitigation across England [25].

The Environmental Yardstick for Pesticides [9] is a DST designed to quantify the environmental impact of the use of pesticides in outdoor and greenhouse crops. The mitigation methods represented are:

- choice of pesticide;

- dose rate;

- $\quad$ application technique (drift); 
- $\quad$ width of untreated buffer zone.

For each pesticide, the yardstick assigns environmental impact points for the risk to aquatic organisms, the risk of leaching to groundwater and the risk to soil organisms (depending on the user-specified soil organic matter content and season of application). The yardstick also shows the associated risk to beneficial organisms, including pollinators and natural predators such as ladybirds, mites and parasitoids. It is used in the Netherlands (and Belgium) as a management tool for farmers and technical consultants, a tool for monitoring the environmental performance of farmers, for setting standards for ecolabels, as guidance for the supply chain to preferentially purchase sustainable agricultural products, and as a policy evaluation tool.

The Catchment-Lake Modelling Network, designed specifically for the Lake Vansjø catchment in Southern Norway, consists of a network of process-based, mass-balance models linking climate, hydrology, catchment-scale P dynamics and lake processes [26]. The model network allows the effects of climate change to be disentangled from those of land-use change on lake water quality and phytoplankton growth, and includes the following mitigation methods:

- land use change;

- cultivation change;

- crop rotation;

- erosion risk reduction measures;

- change in fertiliser application.

The model network can thus support decision-making to achieve good water quality and ecological status within the Lake Vansjø catchment. It was developed to model P and suspended sediment loadings, although it is also possible to include nitrate. The model network is transferable to other catchments; however, it is quite time-consuming to set up and calibrate for a new catchment.

Whilst not directly evaluating the effects of mitigation methods, the UK SCIMAP model [27] provides a framework for generating catchment risk maps for contaminant loss via overland flow pathways, so that the areas within a catchment where mitigation methods are most urgently required can be identified. SCIMAP has been used in the River Eden Demonstration Test Catchment project which is investigating the dynamics of water quality (nutrients and sediments) from agricultural land, and by Durham Wildlife Trust to identify areas with high fine sediment pollution risk within the River Wear catchment. In the Netherlands, BedrijfsWaterWijzer is a web application that is currently being developed to provide a starting point for evaluating measures to reduce emissions to water on dairy farms [28], whilst STONE [29] is a modelling tool wherein various policy measures to reduce nutrient emissions to groundwater and surface waters may be specified.

\subsection{Representation of Economic and Financial Aspects}

The economic and financial implications of implementing mitigation methods were not commonly represented in the shortlisted DSTs. However, FARMSCOPER [22] is able to estimate the cost effectiveness of mitigation methods, singly and in combination, as a cost-efficiency ratio in terms of money $(£)$ saved per \% reduction in nitrate, $\mathrm{P}$ or sediment loss. In addition, the Danish TargetEconN model [30] is an integrated economic and biophysical social planner model, which minimises the costs of meeting a nutrient load reduction target in a specific water body. Some other DSTs do also have the capability to represent economic aspects, e.g., Düngeplanung [20] allows cost comparison of different fertiliser use scenarios.

Future outputs from the FAIRWAY project will provide a more in-depth assessment of the costs and benefits for farmers and society as a whole of using DSTs that directly or indirectly affect water quality.

\subsection{Commentary on DST Uptake and Usage}

There was a wide variation in the number and sophistication of the DSTs available in the different participant countries, reflecting the degree of investment and funding provided. In some countries, 
such as Denmark, a number of different computer-based and online DSTs have been developed aimed at both farmers/advisors (e.g., Mark Online [11], Plant Protection Online [12], Dyrkningsvejledninger [18]) and water quality managers (e.g., CTzoom/Cttools [31], TargetEconN [30]). In contrast, the only DSTs available in Portugal are paper-based manuals and guidelines [32,33], although some of these are also available online. In the absence of other tools capable of modelling agri-environmental measures, Slovenia employs the OECD/Eurostat methodology [34] to calculate N (and P) balances as the basis for reporting Nitrate Directive implementation to the EU, and for the preparation of national policy/legislation and recommendations for farmers on measures for drinking water protection. Slovenia also uses the regional water balance model GROWA-SI developed in Germany for reporting Nitrate Directive implementation at a country wide level [35,36]. Some of the DSTs developed as part of academic research projects are also used internationally, with the results published in the scientific literature. For example, the SCIMAP model developed in the UK has been used in Indonesia to target reforestation to reduce diffuse pollution risks [37].

Figure 3 shows the numbers of users of the shortlisted DSTs (Table A3) for which data was available. In some countries, farmers are obliged under regulations or commercial pressures to use DSTs, and this will clearly affect take-up and user numbers. For example, dairy farmers in the Netherlands who provide milk to Friesland Campina have to use ANCA (Annual Nutrient Cycling Assessment) [38] to analyse nutrient flows and emissions, hence indirectly improving water quality. If they meet certain performance indicators, calculated by ANCA, they can get a bonus for their milk; there are currently c.16,000 users. In the UK, farmers in nitrate vulnerable zones (NVZs) can use a DST such as PLANET [14] to demonstrate compliance with NVZ rules, and it is widely used for this purpose (Figure 3). Düngeplanung, developed in Lower Saxony, Germany [20], is becoming more widely used (currently around 6000 users), following recent changes to regulations which require farmers to produce a fertiliser plan and nutrient balances. In contrast, the number of users is often small for specialised DSTs such as the Norwegian 'Catchment Lake Modelling Network', which comprises a series of process-based, mass-balance models for $\mathrm{P}$ and is designed primarily as a catchment management tool, rather than for general use [26].

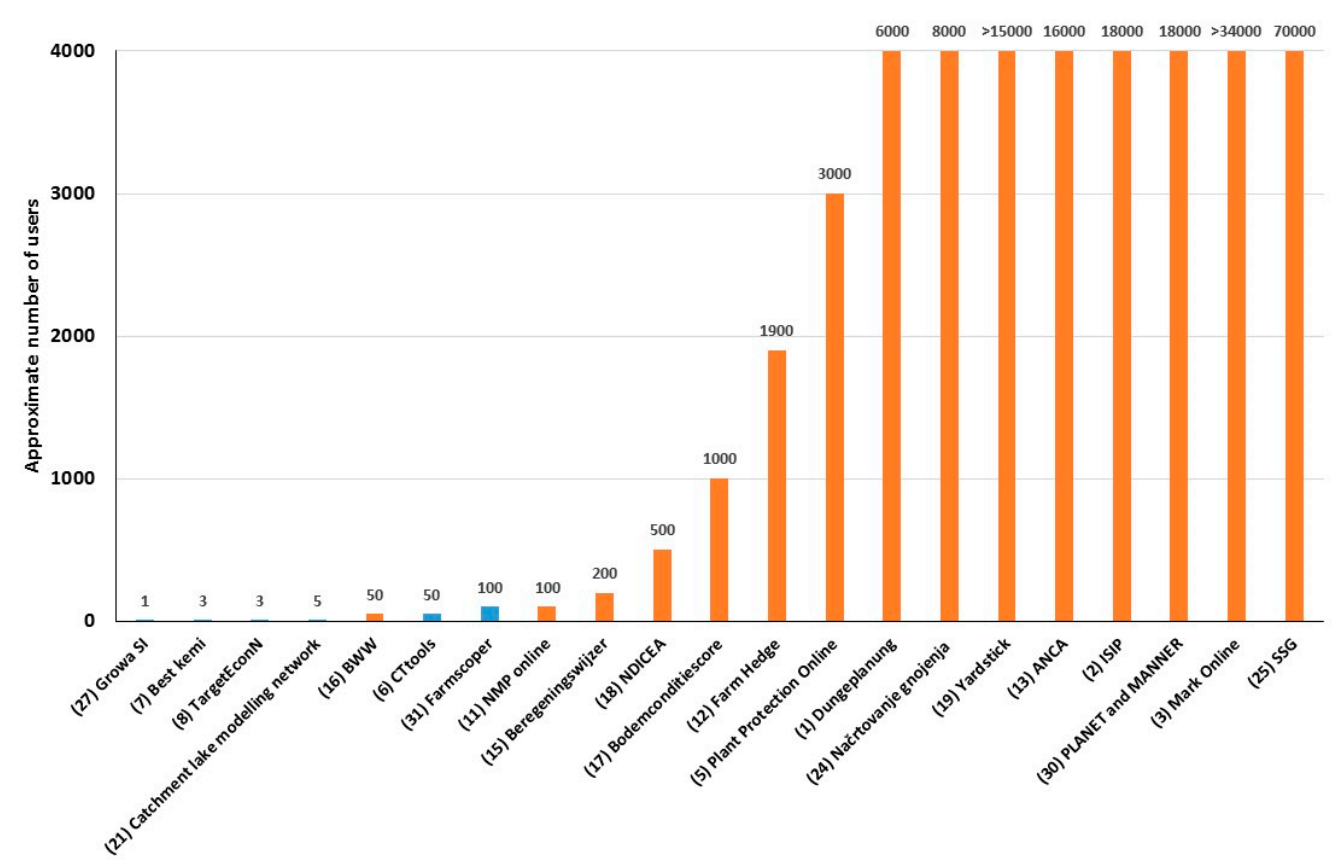

Figure 3. Approximate number of users of the shortlisted DSTs (where data was available). Numbers in brackets on the $\mathrm{x}$-axis refer to the DST number in Table A3. 


\subsection{Barriers to Uptake}

Although some DSTs that cover both nutrients and pesticides (and other aspects of farm management) are available for farmers, some may opt to use more than one DST (or none), depending on their particular needs and requirements, and the legislative and economic environment in which they are operating. DSTs often deal with complex issues, so it is not always easy for farmers to understand and use them-using multiple tools of different types does not always lead to a better decision, as it can be difficult to decide which tools to use under which circumstances.

A recent project undertaken in the UK [39] looked in detail at farmers' usage of the fertiliser recommendations for grassland published in one of the key UK paper-based decision support tools, the Fertiliser Manual (RB209) [40]. Whilst the majority of respondents did not use The Fertiliser Manual (RB209), they described it as 'adequate' as a reference guide. Drawing on information from in-depth interviews and focus groups, the study found that users:

- $\quad$ needed to supplement the information provided with their own information and experience;

- wanted the tool to be more user friendly and flexible; it should be written in 'farmers language';

- thought that potential economic gain should be explicitly demonstrated.

Similarly in Denmark [41], users and non-users of the pesticide DST Plant Protection Online identified several barriers to uptake, including:

- $\quad$ time consuming

- too complicated

- lack of user knowledge (on how to identify weeds and diseases)

- competition from human consultants

- lack of confidence

- only chemical solutions recommended

Another UK study reviewed tools for decision making in agriculture and found that despite their availability in a wide range of formats, uptake in the UK and many other countries has been low [6]. Using a combination of qualitative interviews and quantitative surveys, the authors identified fifteen factors that are influential in convincing farmers and advisers to use DSTs, including:

- usability

- cost-effectiveness

- performance

- relevance to user

- compatibility with compliance demands.

The authors concluded that a better understanding of these factors should lead to more effective DST design and delivery in the future. These authors followed up this work with a study on how stakeholders could be more effectively involved to improve DST design [42]. DST use was explored in a series of 78 interviews and 5 focus groups. Their main suggestion was to assess the decision support context' before building a product. Other requirements were better knowledge of user-centered design practices, a clear understanding of advice systems and greater collaboration with human-computer interaction researchers.

DSTs aimed at policy makers, water quality managers or catchment managers tend to be more complex and require more data. However, the drivers for using such tools are often legislative or policy focused; thus, potential users of a particular DST should be provided with an appropriate level of training and have access to the relevant datasets in order to do so.

\subsection{Evaluation of the DSTs in the Case Studies}

Twelve DSTs were selected for testing and/or demonstration by the participating FAIRWAY case study sites (Table 3). The selected DSTs were a mixture of farm level tools designed to improve 
nutrient or pesticide management on individual farms, and DSTs designed to be used by water quality managers or policy makers at the catchment/regional level, to identify high-risk areas for losses and prioritise mitigation measures or to identify cost-effective management options to decrease nitrate or pesticide pollution.

Table 3. DSTs selected for testing and/or demonstration by the nine participating FAIRWAY case study sites.

\begin{tabular}{|c|c|c|c|}
\hline $\begin{array}{l}\text { Case Study Site } \\
\text { (Country) }\end{array}$ & $\begin{array}{c}\text { DSTs Selected (Owning } \\
\text { Country) }\end{array}$ & Level & Target Pollutant \\
\hline \multirow{3}{*}{ Aalborg (DK) } & $\begin{array}{l}\text { Environmental Yardstick for } \\
\text { Pesticides (NL) }\end{array}$ & Farm & \multirow{3}{*}{ Pesticides } \\
\hline & SIRIS (FR) & Catchment/ region & \\
\hline & TargetEconN (DK) & Catchment/ region & \\
\hline Anglian Region (UK) & $\begin{array}{l}\text { Environmental Yardstick for } \\
\text { Pesticides (NL) }\end{array}$ & Farm & Pesticides \\
\hline La Voulzie (FR) & SIRIS (FR) & Catchment & Pesticides \\
\hline \multirow{2}{*}{ Lower Saxony (DE) } & Mark Online (DK) & Farm & \multirow{2}{*}{ Nutrients } \\
\hline & NDICEA (NL) & Farm & \\
\hline \multirow{3}{*}{ Derg catchment (IE) } & SCIMAP (UK) & Catchment/ region & \multirow{3}{*}{ Pesticides } \\
\hline & Phytopixal (FR); & Catchment/ region & \\
\hline & FARMSCOPER (UK) & Farm & \\
\hline Overijssel (NL) & Düngeplanung (DE) & Farm & Nutrients \\
\hline Noord Brabant (NL) & Plant Protection Online (DK) & Farm & Pesticides \\
\hline Baixo Mondego (PT) & MANNER-NPK (UK) & Farm & Nutrients \\
\hline Dravsko Polje (SI) & ANCA (NL) & Farm & Nutrients \\
\hline
\end{tabular}

During the selection of DSTs for evaluation in the FAIRWAY case study sites, it became clear that many countries have developed similar DSTs to address similar problems. Thus, an important part of the exchange process was to better understand the range of DSTs available in the EU, to compare DSTs from other countries with those already being used in the case study sites and to gain inspiration for enhancing existing DSTs. The information collected using the evaluation schemes for all the DSTs tested in each case study was collated and summarised in terms of: (1) barriers to exchange (2) requirements of a DST in terms of functionality, use and access and (3) stakeholder attitudes to DSTs.

\subsubsection{Barriers to DST Exchange between Countries}

During the selection and testing of the DSTs in the case studies, it became clear that there were a number of barriers which may prevent or limit the use of a DST in a country other than the one for which it was developed.

All the case studies identified language as a key barrier to transferring DSTs between countries, because often the DST and supporting information are only available in the local language. This is especially important when dealing with DSTs which are designed to be used by farmers or advisors who are unlikely to have the time or ability to translate the technical or specialist language which is often used. Nevertheless, it is possible to successfully use a DST developed elsewhere. For example, the Dutch Environmental Yardstick for Pesticides [9] is used in both the Netherlands and Belgium, and is currently being tested with data from US farms; the tool and supporting documentation are available in English. In addition, Plant Protection Online [12], which was developed in Denmark, is being used in the Baltics and Poland, with user information available in Danish, English and German. 
Some DSTs have been developed based on country-specific legislation, which prevents direct exchange with another country, although there may be potential for exchange of part of the DST or to draw on the principles. For example, Mark Online [11] was tested in the Lower Saxony case study in order to assess how Danish legislation might affect practice in Germany. Danish agricultural legislation is quite restrictive in terms of fertiliser practices, but has been shown to produce positive environmental effects (e.g., nitrate concentrations in the upper oxic groundwater have been decreasing significantly in the past 30 years in different Danish reference catchments [43]). The concept of introducing similar strict limitations on $\mathrm{N}$ fertiliser use has been discussed in Germany, but the case study aimed to assess the farm-level implications of such restrictions (i.e., introducing an $\mathrm{N}$ quota) by comparing results from Mark Online with those from Düngeplanung [20], which was already being used. Results indicated that most farmers in the German case study would comply quite well with the Danish legislation, although some would face problems with their current management practices if they had to meet certain requirements (e.g., the obligation to establish cover crops, restricted fertiliser use in autumn, strict soil P-levels). Participants liked several elements of Mark Online, including the modular design, the ability to compile farm management information, and the inclusion of cross-compliance checks; they also thought that linking soil type to yield level would have benefits in the future.

There was great variation in the data requirements for the different DSTs depending on their degree of sophistication, and most case study sites reported this as a barrier to DST exchange. For example, in the Derg case study (Northern Ireland) the farm level data required to populate the some of the spreadsheets in the FARMSCOPER model [22] are not freely available and cannot be used without consent. In addition, data conversion to the required format is often required and this might be difficult for a farmer. For example, when using Mark Online [11] in the Lower Saxony case study, German soil types had to be converted into their Danish equivalents.

Regional differences can also present a barrier for exchange. In the Derg case study, for example, the climate, topography and soil type were markedly different from those in England and Wales, where FARMSCOPER [22] was developed. Ireland has, in general, higher runoff rates and monthly rainfall, and evapotranspiration figures differ from those in England and Wales. Most of these coefficients are pre-calculated for FARMSCOPER and recalibration would be required before the DST could be used effectively. Nevertheless, stakeholders found it to be a potentially powerful tool to support water managers in prioritising the most effective mitigation options in drinking water catchments. Similarly, ANCA, developed in the Netherlands for the assessment of nutrient flows on dairy farms [38], was evaluated at Dravsko Polje (Slovenia). One of the problems encountered was that farms in Slovenia are much smaller than farms in the Netherlands and tend not to specialise, making it difficult to adapt and use the model, which was developed specifically for dairy farms.

Other issues identified as being barriers to exchange were a lack of support and supporting documentation, the requirement for specialised personnel to run complex DSTs and interpret the results (e.g., the DST requires expertise in GIS), and financial cost.

Researchers and policy makers in every country often prefer to develop their 'own' DST rather than use an existing DST from another country, and this often leads to 'reinventing the wheel'. Many DSTs are developed using government funding to address a specific need in a particular country or region, or for a specific crop (e.g. vines, potatoes). Funding is not provided for the benefit of other potential users elsewhere in the EU; the additional cost that this would entail cannot be justified. Commercial DSTs face similar limitations, but tend to be less geographically constrained. These findings are very much in line with the previous research $[44,45]$, which concluded that the involvement of stakeholders in DST development is a prerequisite to successful implementation. In the context of the multi-national aspects of DST use and development considered in the FAIRWAY project, a more logical pathway might be for researchers to organize regular knowledge exchange activities, providing an opportunity to transfer ideas to their own scientific and stakeholder communities. 


\subsubsection{Key DST Requirements in Terms of Functionality, Use, and Access}

The case study evaluation identified a number of requirements for DSTs, in terms of their functionality (cost, accessibility, data input/output and compatibility with other DSTs), use and access.

First and foremost, a DST must be simple (user friendly and self-explanatory), not too time-consuming and practical for farmers/advisors to use. However, the level of complexity depends on the target users and the objective of the DST. Sometimes more complexity is required, particularly in the case of DSTs, which operate at the catchment scale and which aim to simulate complex environmental interactions. The environmental impact of a farm on diffuse contaminant loads (e.g., organic fertiliser runoff) to surface waters, for example, is strongly dependent on hydrological connectivity within the landscape. Representing this spatial variability may not be feasible within many of the export-coefficient based models such as FARMSCOPER [22], so interpretation of outputs requires additional expertise. DSTs which can complete complex calculations for the user (e.g. nutrient load calculations, pesticide dosage needs, etc.) without requiring excessive data inputs (or requiring data to be input more than once) are useful. However, the DST should still provide some flexibility to react to specific situations (e.g., extreme weather events, specific regulation in some areas, etc.) and respect user judgement. For example, users in the Lower Saxony case study liked the way that Mark Online [11] allowed farmers some flexibility on how to allocate nutrients in an agronomically sensible way on their farm, whilst still complying with the farm $\mathrm{N}$ quota.

It is clearly important that a DST should provide correct information and advice e.g., for cross-compliance checking. The introduction of new regulations (which are usually more complex) must be supported by providing some assistance for those affected; to this end, DSTs developed to ensure that farmers and other end users comply with legislation are helpful. Clear information about the derivation of the outputs produced by the DST should be provided (e.g., data source, assumptions applied, etc.), although it is still important to provide a simple and easy tool for establishing whether the legislation/rules are being followed. Examples include Mark Online [11], which includes cross-compliance checking and MANNER-NPK [15] (evaluated in the Portuguese case study), where users thought that being able to flag manure applications which did not comply with NVZ legislation was useful. A well implemented, simple-to use DST can help to ensure that farmers and other end users comply with legislation. However, when new regulations are introduced or the science improves, DSTs must be updated immediately if they are to retain their relevance and the trust of the end user.

Having consistency in the outputs and advice provided by different DSTs is clearly important, and this was not always found to be case. For example, during testing at the Aalborg case study site in Denmark, the Environmental Yardstick for Pesticides [9], SIRIS [21] and Plant Protection Online [12] all gave different results for the risk from pesticides applied to certain crops. Table 4 shows the results of leaching risk assessments for maize and potatoes. Roundup Bio (glyphosate $360 \mathrm{~g} / \mathrm{l}$ ) was assessed to be $82 \%$ using SIRIS (i.e., a high leaching risk), while the Environmental Yardstick for Pesticides indicated a low leaching risk for both soil types and application timings; the Danish assessment was low-medium risk based on the size of the taxes (12 Euros) and the load index to groundwater. One problem was that SIRIS calculates the leaching risk either for groundwater or surface water, making comparison of the outputs difficult. Nevertheless, such differences in results do not inspire stakeholder confidence.

It was found that advisory assistance is often needed to encourage farmers to use DSTs, to assist in their application and to interpret their results. Thus, the success of a DST also crucially depends on the skills and experience of the advisor, who should be able to understand both the science behind and the practical application of the DST and have the skills to communicate complex issues to farmers. Government involvement may, in some cases, increase DST uptake and use (e.g., by making it a legal requirement), although currently adoption is most often driven by market forces. Public recognition of success can also be beneficial, especially for DSTs operating at the catchment level, where a farm or group of farms using a DST could be used to demonstrate best practice. For example, SCIMAP has been used in the co-production of management options to address slurry pollution by the UK Rivers Trust [46], and FARMSCOPER to assess the environmental and economic impacts of revised nutrient and sediment policy measures for catchments across England [25]. 
Table 4. Leaching risk profiles for groundwater calculated using SIRIS, Environmental Yardstick for Pesticides and Plant Protection Online for pesticides used on maize and potatoes, in comparison with the Danish pesticide tax.

\begin{tabular}{|c|c|c|c|c|c|c|c|c|c|}
\hline \multirow[b]{2}{*}{$\begin{array}{c}\text { Danish Pesticide } \\
\text { Name }\end{array}$} & \multirow[b]{2}{*}{ Active Ingredients } & \multirow[b]{2}{*}{$\begin{array}{l}\text { Approved } \\
\text { Dosage }\end{array}$} & \multicolumn{7}{|c|}{ DST Used for Assessment of Leaching Risk to Groundwater } \\
\hline & & & $\begin{array}{c}\text { Danish } \\
\text { Pesticide Tax }{ }^{1}\end{array}$ & $\begin{array}{c}\text { Plant } \\
\text { Protection }\end{array}$ & SIRIS $^{3}$ & \multicolumn{4}{|c|}{ Environmental Yardstick for Pesticides ${ }^{4}$} \\
\hline & & & $\begin{array}{l}\text { (Euro per kg } \\
\quad \text { or l) }\end{array}$ & (Load index) & (Rank-ing \%) & \multicolumn{4}{|c|}{ (EIP at recommended product dose) } \\
\hline & & & & & & \multicolumn{2}{|c|}{$1.5 \% \mathrm{SOM}$} & \multicolumn{2}{|c|}{$1.5-3 \%$ SOM } \\
\hline & & & & & & Spring & Autumn & Spring & Autumn \\
\hline Callisto & Mesotrion & 1.51 & 19 & 0.10 & 41 & 227 & 2087 & 58 & 530 \\
\hline MaisTer & $\begin{array}{l}\text { Foramsulfuron/ } \\
\text { iodosulfuron-methyl- } \\
\text { Na/isoxadifen-ethyl }\end{array}$ & $0.15 \mathrm{~kg}$ & 2 & 0.01 & 55 & 7 & 94 & 6 & 89 \\
\hline Harmony SX & Thifensulfuron-methyl & $15 \mathrm{~g} / \mathrm{ha}$ & 2 & & 63 & 0 & 0 & 0 & 0 \\
\hline Starane $333 \mathrm{HL}$ & Fluroxypyr & 0.8111 & 9 & 0.01 & 71 & 27 & 2701 & 3 & 270 \\
\hline Fighter 480 & Bentazon & 1.041 & 7 & 0.19 & 82 & 58 & 519 & 52 & 324 \\
\hline Roundup Bio & Glyphosate & 3.51 & 12 & 0.17 & 82 & 0 & 0 & 0 & 0 \\
\hline Reglone & Diquat dibromid & 41 & 79 & & 82 & 0 & 0 & 0 & 0 \\
\hline Proman & Metobromuron & 41 & & & 91 & 2740 & 9340 & 212 & 456 \\
\hline Boxer & Prosulfocarb & 3.51 & 58 & 1.20 & 60 & 0 & 172 & 0 & 3 \\
\hline Agil $100 \mathrm{EC}$ & Propaquizafop & 1.251 & 13 & 0.07 & 47 & 1 & 2 & 0 & 0 \\
\hline Focus Ultra & Cycloxydim & 51 & 29 & 0.01 & & 1300 & 8000 & 650 & 1050 \\
\hline Ranman & Cyazofamid & 0.21 & 1 & & 23 & 87 & 62 & 6 & 6 \\
\hline Shirlan & Fluazinam & 0.41 & 7 & & 31 & 381 & 442 & 54 & 66 \\
\hline Acrobat New & $\begin{array}{l}\text { Dimethomorph/ } \\
\text { mancozeb }\end{array}$ & $1.68 \mathrm{~kg}$ & 23 & & 91 & 118 & 715 & 8 & 475 \\
\hline Cyperb 100 & Cypermethrin & 0.41 & 85 & 0.03 & 18 & 0 & 0 & 0 & 0 \\
\hline Karate 2,5 WG & Lambda-cyhalothrin & $0.3 \mathrm{~kg}$ & 13 & 0.01 & & 0 & 0 & 0 & 0 \\
\hline
\end{tabular}

${ }^{1}$ The Danish Pesticide Tax scheme is based on the pesticide load index (see footnote 2) for three sub-indicators for human health, ecotoxicology and environmental fate, respectively. The tax increases as the risk of the pesticide increases; ${ }^{2}$ Plant Protection Online classifies pesticides according to the pesticide load index, which is an indicator of pesticide risk [47]. In Denmark, the pesticide load is based on three sub-indicators for human health, ecotoxicology and environmental fate. In the table, only the pesticide load index for the environmental fate sub-indicator is presented, so that comparisons between DSTs assessment of pesticide leaching to groundwater could be made. Red indicates high risk with regard to environmental fate (i.e., a measure of the degradation time of a pesticide in soil and its potential for accumulation in food chains and for transport to groundwater), orange indicates medium risk and green low risk; ${ }^{3}$ SIRIS classifies pesticides according to their potential to reach surface or groundwater. Results are expressed as rankings representing risk. In this example, the risk of the various pesticides leaching to groundwater is shown; ${ }^{4}$ The Environmental Yardstick for Pesticides assigns environment impact points (EIP) to a pesticide: EIP $>1000$ indicates high risk (red); EIP (100-1000) indicates medium risk (orange); EIP < 100 indicates low risk (green). In this example, risk was calculated for soils with 1.5\% and 1.5-3.0\% soil organic matter (SOM), for applications in spring and autumn. 
Conversely, where advisory services are limited or non-existent, a well-designed DST can provide useful guidance for protecting drinking water quality. This is particularly relevant for pesticides, where farmers rarely have detailed knowledge of the environmental behaviour of specific products.

\subsubsection{Attitudes towards Decision Support Tools}

In the case studies, DST users and other stakeholders were asked about their attitudes towards and main requirements for DSTs. 'Ease of use' and 'assistance with compliance' were frequently mentioned as being important in determining whether or not a DST was used. 'Ease of use' encompasses a range of reported user requirements such as:

Intuitive design;

- A centralized and holistic approach, where data only needs to be entered once;

- Checks to avoid data input errors and avoid wasting time;

- Data input and presentation of results (web-interface, excel-sheet, pdf, etc.) designed to suit user preferences;

- Clear results and outputs (e.g., graphical representations).

Similarly, in terms of 'assistance with compliance' users identified requirements such as:

- Trustworthy and reliable results (farmers cannot verify the data themselves, so must have confidence not only in the DST, but also in the developers of the DST);

- Availability of supplementary supporting information;

- Frequent updates to ensure compliance with legal requirements (if a farmer is to invest in a DST, then a 'future proof' tool is needed).

The feedback from the FAIRWAY case studies adds to findings from previous studies. For example, ease of use, defined as the ability of DSTs to present information to the user in a clear and familiar way with rapid comprehension, was highlighted as a concern by Inman et al. [48] Similarly, an EIP-AGRI workshop on "Tools for Environmental Farm Performance" [49] found that the reasons for poor uptake of DSTs among farmers include:

- the tool is not found to be useful by the farmer;

- the tool might be difficult to understand;

- the DST may require the farmer to spend a lot of time setting it up or learning how to use it;

- the costs outweigh the perceived benefits.

In summary, a DST that is acceptable to the majority of end users should fulfil most if not all of the criteria shown in Figure 4. A DST that fulfils these criteria and can deliver a range of functions is more likely to be successful, as end users prefer to limit the number of DSTs that they are required to use. Additionally, the provision of good advisory assistance was highlighted as being of great importance. The results produced by a DST are only as good as the input data, therefore support and advice from skilled advisors is highly valued by end users to enable them to make the right decisions. 


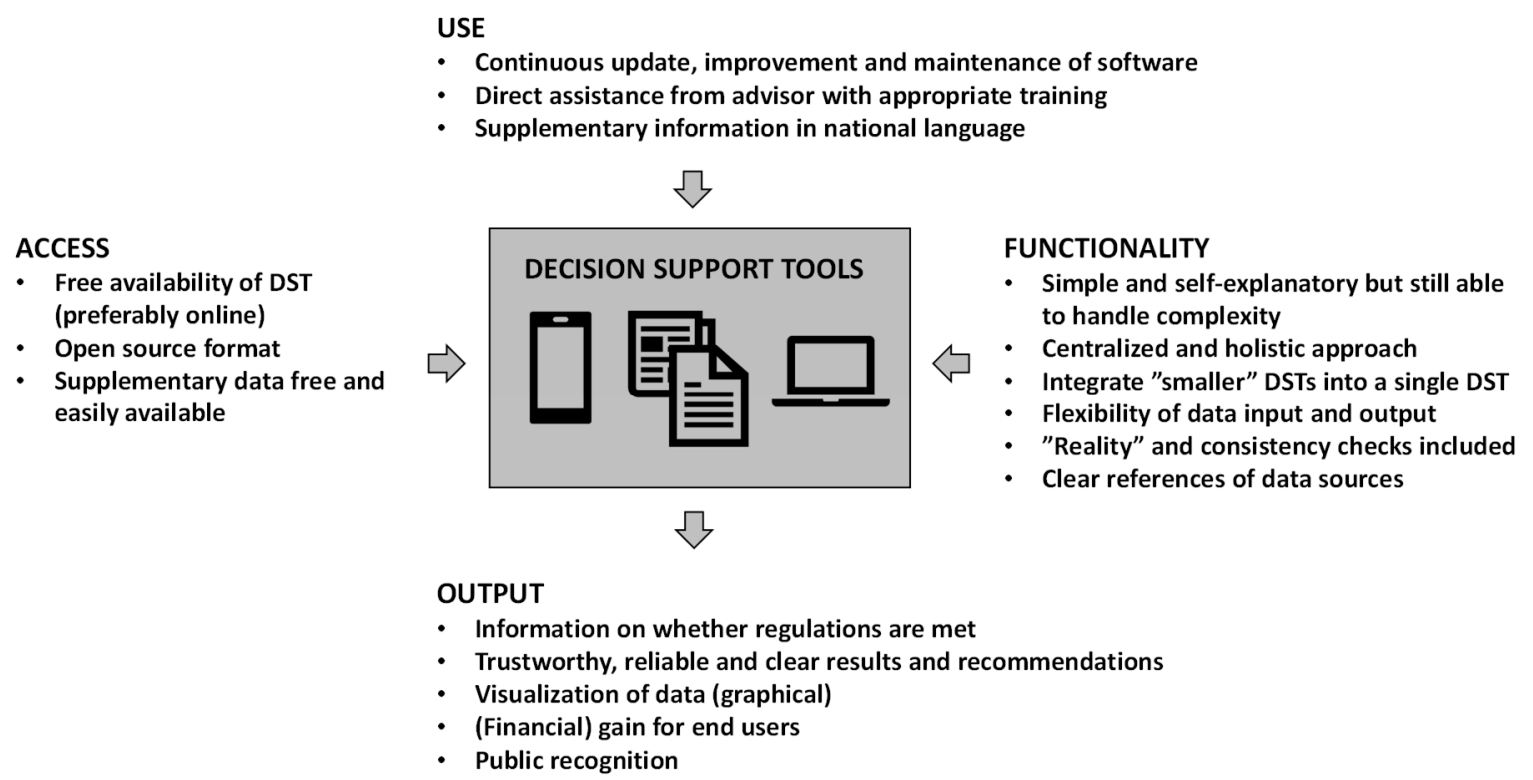

Figure 4. Criteria to be fulfilled by DSTs as identified by end users in nine FAIRWAY case studies.

\subsection{Wider Perspectives and Future Developments}

Despite the difficulties with the international exchange of DSTs, there are initiatives underway in the EU where partners from different MS are collaborating to develop tools which will have a direct or indirect impact on water quality.

An EU-funded project with similar aims to FAIRWAY is WaterProtect [50]. In this project, the aim is to "create or develop collaborative webtools and mobile apps that facilitate and more effectively implement farm management practices and measures for the protection of the drinking water sources". The project partners are building collaborative webtools for their Actionlabs (equivalent to the case studies implemented this study) that will help local actors (farmers, environment agencies, drinking water producers, and others) to monitor water quality, and to decide where to effectively implement management practices and measures to protect water sources. The tools will include information from the participatory monitoring, landscape information, best management practices and their socio-economic benefits and costs, although at present, the only tool available is for Belgium [50]. This is an online webtool presenting results from pesticide water sampling catchments in the form of online maps, so that local communities are able to access information pertaining to their area. As such, it appears to be a 'citizen science' application rather than a farm decision making or policy tool, such as those considered in our study.

Additionally, there is a tool which is under development as part of the future CAP preparations, and this is the Farm Sustainability Tool for Nutrients (FaST), an EU-wide tool which aims to help all farmers in the EU, without access to equivalent national DSTs, to manage the use of nutrients on their farms [51]. The FaST tool was not available for assessment as part of the FAIRWAY project and is still under development, however it will be interesting to follow its uptake, performance and implementation, as it is the first farm nutrient management DST that will have full EU coverage, and to see how the developers address the challenges identified in this study.

Over the next decade, the development of the DSTs and technologies to support the objectives within the CAP will be critical considerations. Extending and tightening further blanket measures (e.g., closed spreading periods) has limited the potential within some MS to deliver improvements without negatively impacting production. Measures to improve water quality must therefore transform toward more targeted farm- and catchment-specific approaches, using best available data and knowledge. Tools which can simplify these often complex decisions and matrices of scenarios will be critical if uptake targets are to be reached and maximum benefits delivered for users. The 
problem is whether there is the political will to collect the required data, and whether it is possible to collect it in such a way that any trans-national DSTs can be used consistently across the EU.

\section{Summary and Conclusions}

The EU FAIRWAY project was established to review approaches for protecting drinking water from nitrate and pesticide pollution. As part of the project, a comprehensive overview of DSTs used by farmers, farm advisors, water managers and policy makers for water, nutrient and pesticide management was undertaken, encompassing paper-based guidelines, farm-level software and phone apps, and complex research models. The unique combination of expertise and practical experience of the FAIRWAY project participants was used to identify farm-scale tools and other locally developed DSTs of importance in a national context. Of the $>150$ DSTs identified, 36 were selected for further investigation based on their national importance and relevance to the project aim. The majority of the selected DSTs were farm management tools and were included under the assumption that smart use of nutrients/pesticides indirectly improves water quality by reducing losses to the water environment. Only three of the selected DSTs were explicitly developed to consider the impact of mitigation methods on water quality.

Following demonstration and evaluation, 12 DSTs were selected for practical testing at nine of the FAIRWAY case study sites, to best match the challenges faced at each location. During the trial period, the DSTs were populated using local data, and meetings and demonstrations to stakeholders were organised. Barriers to DST exchange between countries were identified, and information was collected about farmer/stakeholder requirements and attitudes.

The FAIRWAY project provided a unique opportunity to exchange and test DSTs in very different environments across several MS. The evaluations indicated that the exchange of DSTs between MS is challenging because of the different legislative environments, advisory frameworks, country-specific data/calibration requirements, regional climate/soil differences, and issues around language. Notably, DSTs from different countries using the same input data sometimes delivered very different results. Whilst many countries have developed comparable DSTs designed to address similar problems, all the case study participants were able to draw inspiration and ideas from elsewhere. The support and advice provided by skilled advisors was highly valued, empowering end users to use the outputs from DSTs to make decisions for protecting water quality.

The case study evaluations will aid the development of a framework to highlight how DSTs can be used to improve awareness of diffuse pollution of vulnerable drinking water resources among farmers and other stakeholders, and will contribute to the wider Fairway project objective of identifying and developing innovative approaches for more effective drinking water protection.

Author Contributions: Methodology, F.N., R.K.L., R.C., L.T., N.S. and J.W.; Data Curation, F.N. and R.K.L.; Writing —Original Draft Preparation, F.N.; Writing-Review and Editing, R.C., L.F., L.T., R.K.L., N.S., and G.V.; Visualization, L.T., R.C. and R.K.L.; Supervision, R.K.L. and J.W.; Funding Acquisition, J.W. and G.V. All authors have read and agreed to the published version of the manuscript.

Funding: This research was funded by the European Union's Horizon 2020 research and innovation programme under grant agreement No 727984.

Acknowledgments: We are grateful to the following people who participated and contributed to the FAIRWAY project, and to the work presented in this paper: D. Doody (AFBI), A. Ferriera (IPC/ESAC), A. Jamsek (KGZ Maribor), Ø. Kaste (NIVA), S. Langas (NIVA), P. Schipper (WUR), J. Van Vliet (CLM), K. Verloop (WUR), F. Bondgaard (SEGES), M. Jørgensen (SEGES), I. Wright (UoL), J. Rowbottom (UoL), I. A. Leitão (IPC/ESAC), B. Hasler (AU), M. Glavan (UL), P. Leendertse (CLM), M. Hoogendoorn (CLM) and L. Jackson-Blake (NIVA).

Conflicts of Interest: The authors declare no conflict of interest. The funders had no role in the design of the study; in the collection, analyses, or interpretation of data; in the writing of the manuscript, or in the decision to publish the results. 


\section{Appendix A}

Table A1. Keywords used for the online literature search (Web of Science).

\begin{tabular}{cccc}
\hline Search Term & \multicolumn{2}{c}{ Keywords } & \\
\hline \multirow{4}{*}{ DST } & Decision support tool OR & Guidance software OR & Decision management system \\
& Software tool OR & Decision support & OR \\
& Guidance tool OR & software OR & Decision assistance tool OR \\
& AND & Decision support system & Calculator OR \\
& Agricultur* OR & OR & App* \\
& Farm* OR & Nitrate* OR & Glyphosate OR \\
& Financial cost* OR & Ammonium OR & Bentazon OR \\
& Social cost* OR & Pesticide OR & Organochlor* OR \\
& Cost-effective* OR & Herbicide OR & Tryazine OR \\
& Welfare* OR & Fungicide OR & Dinitroaniline OR \\
& Cost-benefit OR & Molluscicide OR & Bipiridil OR \\
Policy* OR & Insecticide OR & Dithiocarbamate OR \\
& Water quality OR & Weed control OR & Triazole OR \\
Pollutant/effect & Water* OR & Weed manage* OR & Pyrethroid OR \\
& Groundwater OR & Growth regulat* OR & Amide OR \\
& Aquifer OR & Metaldehyde OR & Sulfonylurea OR \\
& Soil $^{*}$ OR & Organophosphate OR & Uracil OR \\
& Fertili* OR & Carbamate OR & Benzimidazole OR \\
& Rush* OR & Diazine OR & Nematicide OR \\
& Nitrogen OR & Phenoxyacetic acid OR & Acaricide OR \\
Nutrient* OR & MCPA OR & Slimicide \\
\hline
\end{tabular}

Table A2. Details for each DST supplied by FAIRWAY project partners.

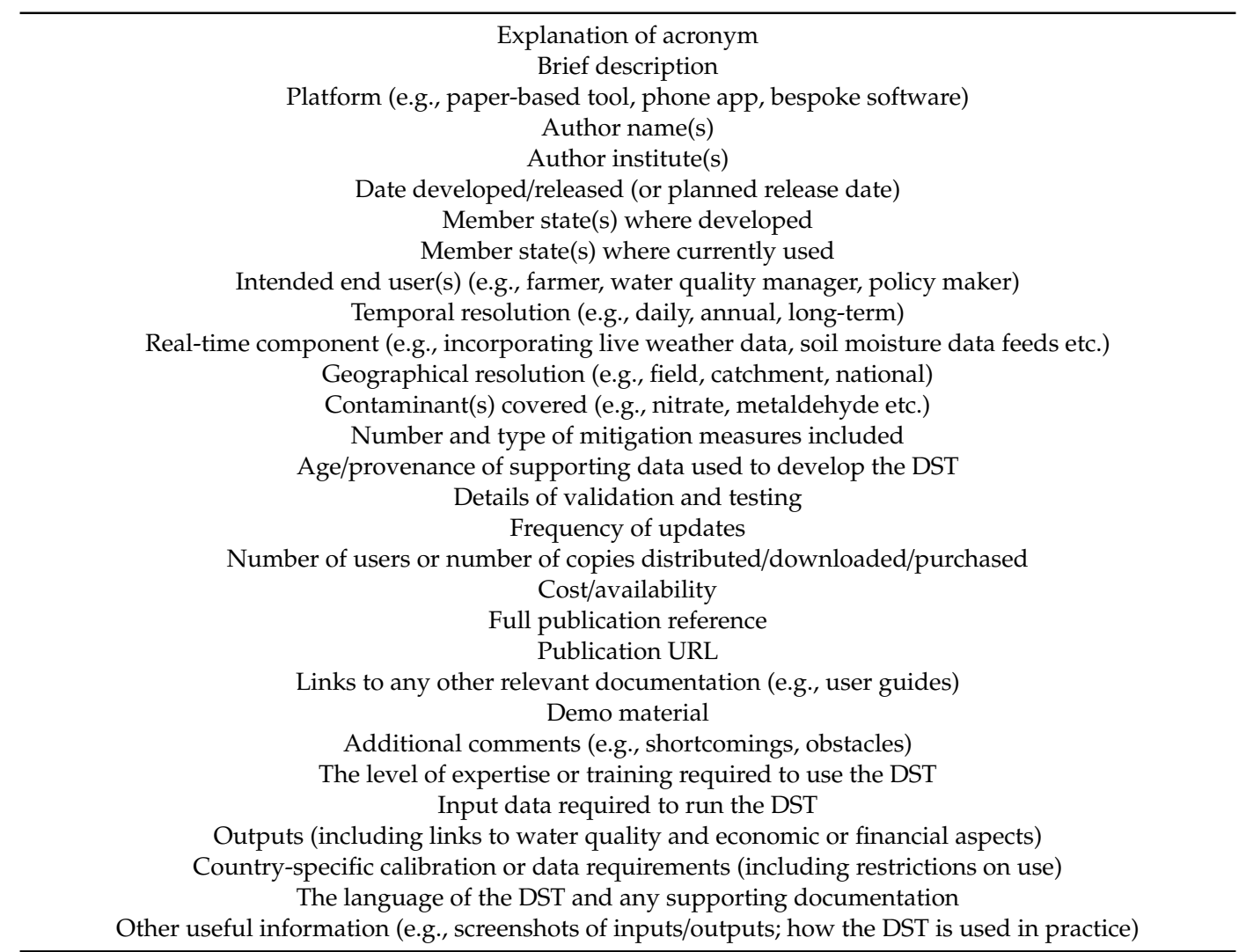


Table A3. Shortlist of DSTs taken forward for further consideration, including summary description and publication reference (where applicable).

\begin{tabular}{|c|c|c|c|c|c|c|c|c|}
\hline No. & Country & DST Name & Type of DST ${ }^{1}$ & $\mathrm{WQI}^{\mathbf{1}}$ & $\mathrm{WQ}^{2}$ & Mitigation $^{3}$ & Brief Description & Reference \\
\hline 1 & $\mathrm{DE}$ & Düngeplanung & Nutrient & $\mathrm{Y}$ & & & $\begin{array}{l}\text { Farm-holistic DST to guide fertiliser purchasing } \\
\text { and field-specific distribution. Combines } \\
\text { on-farm data (soil nutrient contents, farm } \\
\text { manure analysis, etc.), information on crop } \\
\text { cultivation (crop rotation, yield level, etc.) with } \\
\text { economic factors. }\end{array}$ & [20] \\
\hline 2 & $\mathrm{DE}$ & ISIP & Nutrient & & Y & & $\begin{array}{l}\text { Process-oriented model which simulates } \\
\mathrm{N} \text {-mineralisation in the soil and adjusts } \\
\text { real-time recommendation for N-fertilisers in } \\
\text { winter wheat accordingly. }\end{array}$ & [52] \\
\hline 3 & DK & Mark Online & $\begin{array}{l}\text { Nutrient/ } \\
\text { Pesticide }\end{array}$ & $\mathrm{Y}$ & & & $\begin{array}{l}\text { Used by farmers and advisors for fertiliser } \\
\text { planning, optimization and documentation. } \\
\text { Covers all aspects of crop management } \\
\text { including soil tillage and crop protection. } \\
\text { Ensures that pesticides and nutrients are used } \\
\text { according to legislation based on data obtained } \\
\text { via field trials. }\end{array}$ & [11] \\
\hline 4 & DK & $\begin{array}{l}\text { Dyrknings- } \\
\text { vejledninger }\end{array}$ & $\begin{array}{l}\text { Nutrient/ } \\
\text { Pesticide }\end{array}$ & & & & $\begin{array}{l}\text { Manuals for growing a broad range of } \\
\text { agricultural crops based on results from field } \\
\text { trials. Updated at least annually to inform } \\
\text { farmers/advisors on all aspects of Good } \\
\text { Agricultural Practice. }\end{array}$ & [18] \\
\hline 5 & DK & $\begin{array}{l}\text { Plant Protection } \\
\text { Online }\end{array}$ & Pesticide & & & & $\begin{array}{l}\text { Used by farmers and advisors to reduce } \\
\text { pesticide use and ensure that only legal } \\
\text { pesticides are used. The tool gives } \\
\text { recommendations on whether or not to spray, } \\
\text { dosage and spraying time. }\end{array}$ & [12] \\
\hline 6 & DK & CTzoom/CTtools & Nutrient & & Y & & $\begin{array}{l}\text { Estimates nitrate leaching based on } \mathrm{N} \text { surplus } \\
\text { calculations for individual fields. The results } \\
\text { are used to define current practices. }\end{array}$ & [31] \\
\hline
\end{tabular}


Table A3. Cont.

\begin{tabular}{|c|c|c|c|c|c|c|c|c|}
\hline No. & Country & DST Name & Type of DST ${ }^{1}$ & $\mathrm{WQI}^{1}$ & $W^{2}$ & Mitigation $^{3}$ & Brief Description & Reference \\
\hline 7 & DK & BEST Kemi & Nutrient & & $\mathrm{Y}$ & & $\begin{array}{l}\text { Groundwater management and forecasting DST } \\
\text { used by the state and utilities to assess aquifer } \\
\text { nitrate and pesticide concentrations. Can also } \\
\text { monitor trends in groundwater quality. }\end{array}$ & NA \\
\hline 8 & DK & TargetEconN & Nutrient & Y & & & $\begin{array}{c}\text { Integrated economic and biophysical social } \\
\text { planning model which minimises the costs of } \\
\text { meeting a nutrient load reduction target. } \\
\text { Calibrated for the the Danish Fjord Limfjorden } \\
\text { watershed and currently being set up for } \\
\text { Denmark as a whole. Used for WFD policy } \\
\text { advice. }\end{array}$ & {$[30]$} \\
\hline 9 & FR & PHYTOPIXAL & Pesticide & Y & & & $\begin{array}{l}\text { GIS model based on a combination of indicators } \\
\text { relating to the environmental vulnerability of } \\
\text { the surface water environment and the } \\
\text { agricultural pressure to estimate contamination } \\
\text { risk. }\end{array}$ & [53] \\
\hline 10 & FR & SIRIS & Pesticide & & & & $\begin{array}{l}\text { Classifies pesticides according to their potential } \\
\text { to reach surface or groundwater. Results } \\
\text { expressed as rankings representing risk. Helps } \\
\text { farmers select the best product according } \\
\text { environment parameters. Aids pesticide } \\
\text { monitoring in waters at regional or local scale. }\end{array}$ & [21] \\
\hline 11 & IE & $\begin{array}{l}\text { Teagasc NMP } \\
\text { online }\end{array}$ & Nutrient & & & & $\begin{array}{l}\text { System for developing farm-scale nutrient } \\
\text { management plans for environmental and } \\
\text { regulatory purposes. Likely to be used by } \\
\text { agricultural consultants on behalf of most } \\
\text { farmers. }\end{array}$ & {$[54]$} \\
\hline 12 & IE & FarmHedge & Pesticide & & & & $\begin{array}{c}\text { Commercial phone app to manage } \\
\text { feed/fertiliser purchases with a secondary } \\
\text { component using farm location to create a set of } \\
\text { weather alerts and advice on minimising } \\
\text { environmental impact. }\end{array}$ & [10] \\
\hline
\end{tabular}


Table A3. Cont.

\begin{tabular}{|c|c|c|c|c|c|c|c|c|}
\hline No. & Country & DST Name & Type of DST ${ }^{1}$ & $\mathrm{WQI}^{1}$ & $W^{2}$ & Mitigation $^{3}$ & Brief Description & Reference \\
\hline 13 & NL & ANCA & Nutrient & Y & & & $\begin{array}{l}\text { Farm specific assessment of nutrient } \\
\text { inputs/outputs and emissions to the } \\
\text { environment used by advisors to improve } \\
\text { on-farm nutrient efficiency. Used as a } \\
\text { monitoring tool to evaluate the effects of } \\
\text { mitigation measures and by policy makers to } \\
\text { estimate catchment N \& P surplus reductions.. }\end{array}$ & [38] \\
\hline 14 & NL & $\begin{array}{c}\text { Adviesbasis } \\
\text { CBGV }\end{array}$ & Nutrient & & & & $\begin{array}{c}\text { Recommendations for fertilisation of grassland } \\
\text { and maize. } \mathrm{N} \text { rates specified for different } \\
\text { growing conditions e.g., soil type, } \mathrm{N} \text { release in } \\
\text { soil by mineralisation and hydrology (water } \\
\text { availability). }\end{array}$ & [55] \\
\hline 15 & NL & Beregeningswijzer & Nutrient & & & & $\begin{array}{c}\text { Online meteorological data and field data are } \\
\text { used to provide optimum irrigation } \\
\text { requirements for individual fields. Prevents } \\
\text { excess irrigation which could enhance leaching. } \\
\text { Preserves optimal soil water content, resulting } \\
\text { in higher N uptake and better fertiliser N } \\
\text { utilization. }\end{array}$ & {$[56]$} \\
\hline 16 & NL & $\begin{array}{l}\text { BedrijfsWaterWijzer } \\
\quad \text { (BWW) }\end{array}$ & Nutrient & & $\mathrm{Y}$ & & $\begin{array}{l}\text { Identifies risks to water quality specific to dairy } \\
\text { farms and suggests measures for improvement. } \\
\text { The risks are scored qualitatively (Good, } \\
\text { Moderate, Insufficient, Bad). Enables farmers to } \\
\text { indirectly evaluate the effect of mitigation } \\
\text { measures. }\end{array}$ & [28] \\
\hline 17 & NL & Bodemconditiescore & $\begin{array}{l}\text { Nutrient/ } \\
\text { Pesticide }\end{array}$ & & & & $\begin{array}{l}\text { Evaluation method for visual observations of } \\
\text { sod density, botanical composition of grass sod, } \\
\text { soil density, biological activity, abundance of } \\
\text { macro fauna, rooting depth. Optionally also } \\
\text { chemical quality of the grass and maize silage. } \\
\text { Supports farmers by indicating soil problems. }\end{array}$ & [19] \\
\hline
\end{tabular}


Table A3. Cont.

\begin{tabular}{|c|c|c|c|c|c|c|c|c|}
\hline No. & Country & DST Name & Type of DST ${ }^{1}$ & WQI $^{1}$ & $W^{2}$ & Mitigation $^{3}$ & Brief Description & Reference \\
\hline 18 & NL & NDICEA & Nutrient & & & & $\begin{array}{c}\text { Planner for integrated assessment of } \mathrm{N} \\
\text { availability for crops. Accounts for crop } \mathrm{N} \\
\text { demand, expected } \mathrm{N} \text { availability from artificial } \\
\text { fertilisers and manures, crop residues, green } \\
\text { manures and soil, as well as leaching and } \\
\text { denitrification losses. }\end{array}$ & [13] \\
\hline 19 & NL & $\begin{array}{l}\text { Environmental } \\
\text { Yardstick for } \\
\text { Pesticides } \\
\text { (Yardstick) }\end{array}$ & Pesticide & & $\mathrm{Y}$ & Y & $\begin{array}{l}\text { Online version and crop information sheets to } \\
\text { support on-farm integrated pesticide } \\
\text { management. An offline version evaluates } \\
\text { current practices and the effect of mitigation } \\
\text { measures. Spraying schemes are evaluated in } \\
\text { terms of environmental impact. Provides water } \\
\text { utilities with a proxy for the value of programs } \\
\text { designed to reduce impacts on groundwater. }\end{array}$ & [9] \\
\hline 20 & NL & STONE & Nutrient & & & & $\begin{array}{l}\text { Calculates nutrient emissions to water and } \\
\text { evaluates the effects of fertiliser policy measures } \\
\text { on runoff and leaching of } \mathrm{N} \text { and } \mathrm{P} \text { to waters at } \\
\text { national and regional levels. Can distinguish } \\
\text { processes and sources of runoff and leaching to } \\
\text { water. Used by policy makers to introduce } \\
\text { effective mitigation measures and allocate } \\
\text { source reduction targets }\end{array}$ & [29] \\
\hline 21 & $\mathrm{NO}$ & $\begin{array}{c}\text { Catchment-Lake } \\
\text { Modelling } \\
\text { Network } \\
\text { (CLMN) }\end{array}$ & Nutrient & & Y & Y & $\begin{array}{l}\text { Network of process-based, mass-balance } \\
\text { models linking climate, hydrology, } \\
\text { catchment-scale nutrient dynamics and lake } \\
\text { processes. Allows disentangling of the effects of } \\
\text { climate change from those of land-use change } \\
\text { on lake water quality and phytoplankton } \\
\text { growth. Supports decision-making to achieve } \\
\text { good water quality and ecological status. }\end{array}$ & [26] \\
\hline 22 & $\mathrm{NO}$ & Skifteplan & Nutrient & Y & & & $\begin{array}{l}\text { Most commonly used farm level DST for } \\
\text { fertiliser application on agricultural fields. } \\
\text { Calculates optimal fertilisation rates, to avoid } \\
\text { excess } \mathrm{N} \text { and } \mathrm{P} \text { in soils and runoff. Also used to } \\
\text { record crops grown in each field and year, and } \\
\text { other treatments/measures implemented. }\end{array}$ & [57] \\
\hline
\end{tabular}


Table A3. Cont.

\begin{tabular}{|c|c|c|c|c|c|c|c|c|}
\hline No. & Country & DST Name & Type of DST ${ }^{1}$ & WQI $^{1}$ & $W^{2}$ & Mitigation $^{3}$ & Brief Description & Reference \\
\hline 23 & $\mathrm{NO}$ & $\begin{array}{l}\text { Agro-Meteo-rological } \\
\text { Service }\end{array}$ & 1 & & & & $\begin{array}{l}\text { Run by NIBIO in collaboration with the } \\
\text { Norwegian Met. Office. Provides } \\
\text { meteorological data for better management of } \\
\text { risks from farm operations in important } \\
\text { agricultural districts. }\end{array}$ & [17] \\
\hline 24 & SI & $\begin{array}{c}\text { Načrtovanje } \\
\text { Gnojenja }\end{array}$ & Nutrient & & & & $\begin{array}{l}\text { Assists agricultural advisers/farmers to } \\
\text { optimise fertiliser use in all agricultural sectors } \\
\text { as annual or multi-year fertiliser plans. Advises } \\
\text { on crop rotations. }\end{array}$ & NA \\
\hline 25 & SI & $\begin{array}{l}\text { Smernice za } \\
\text { Strokovno } \\
\text { Gnojenje (SSG) }\end{array}$ & Nutrient & & & & $\begin{array}{l}\text { Fertiliser use guidelines which comply with the } \\
\text { regulations and requirements for the quality of } \\
\text { crops and the preservation of a clean } \\
\text { environment. Intended to set a broader } \\
\text { framework based on rational expert findings. }\end{array}$ & [58] \\
\hline 26 & SI & $\begin{array}{l}\text { OECD/EUROSTAT } \\
\text { N Balance } \\
\text { (OENBAL) }\end{array}$ & Nutrient & $\mathrm{Y}$ & & & $\begin{array}{l}\text { Paper based handbook of methodology for } \\
\text { calculating N and P balances in OECD/EU MS. } \\
\text { Provides a consistent indicator based on } \\
\text { harmonised methodology and definitions. Used } \\
\text { to report on Nitrate Directive implantation and } \\
\text { prepare legislation/measures for drinking water } \\
\text { protection. }\end{array}$ & [32] \\
\hline 27 & SI & GROWA-SI & Nutrient & & $\mathrm{Y}$ & & $\begin{array}{l}\text { This regional water balance model is the official } \\
\text { state model for reporting of Nitrate Directive } \\
\text { implementation at a country level. Can } \\
\text { calculate groundwater recharge rates and has } \\
\text { the capability to account for } \mathrm{N} \text { balances. }\end{array}$ & {$[35,36]$} \\
\hline 28 & SI & $\begin{array}{l}\text { State Network } \\
\text { of Groundwater } \\
\text { Monitoring } \\
\text { Points (SNGMP) }\end{array}$ & $\begin{array}{l}\text { Nutrient/ } \\
\text { Pesticide }\end{array}$ & & Y & & $\begin{array}{l}\text { State approved water quality monitoring } \\
\text { network used by key decision makers. } \\
\text { Measured values and their trends over the years } \\
\text { serve as one of the base indicators for } \\
\text { introducing new measures and indicate the } \\
\text { success of previously introduced measures. }\end{array}$ & [59] \\
\hline
\end{tabular}


Table A3. Cont.

\begin{tabular}{|c|c|c|c|c|c|c|c|c|}
\hline No. & Country & DST Name & Type of DST ${ }^{1}$ & WQI $^{1}$ & $W^{2}$ & Mitigation $^{3}$ & Brief Description & Reference \\
\hline 29 & SI & FITO-INFO & Pesticide & & & & $\begin{array}{l}\text { Slovenian public information system for plant } \\
\text { protection which includes: plant protection } \\
\text { products; related legislation; organism names, } \\
\text { descriptions, pictures, weather forecasts etc. }\end{array}$ & {$[60]$} \\
\hline 30 & UK & PLANET/MANNER & Nutrient & $\mathrm{Y}$ & & & $\begin{array}{c}\text { Nutrient management DSTs for use by } \\
\text { farmers/advisers for field level nutrient } \\
\text { planning and demonstrating compliance with } \\
\text { NVZ rules. }\end{array}$ & {$[14,15]$} \\
\hline 31 & UK & FARMSCOPER & Nutrient/pesticide & & Y & $\mathrm{Y}$ & $\begin{array}{l}\text { Assesses diffuse agricultural pollutant loads on } \\
\text { a farm and quantifies the impacts of mitigation } \\
\text { methods. Can be customised to reflect } \\
\text { management and environmental conditions } \\
\text { representative of farming across England \& } \\
\text { Wales. Contains over } 100 \text { mitigation methods. }\end{array}$ & [22] \\
\hline 32 & UK & Check it Out & Pesticide & & & & $\begin{array}{c}\text { Helps farmers/sprayer operators review and } \\
\text { improve spraying practices and reduce the risk } \\
\text { of pesticides reaching water. Each aspect of the } \\
\text { spraying operation is scored and a total } \\
\text { provided. }\end{array}$ & [61] \\
\hline 33 & UK & Sentinel Online & Pesticide & & & & $\begin{array}{l}\text { Online information system to make key } \\
\text { decisions in crop management. Includes: The } \\
\text { Pesticide Database; Library; Decision support } \\
\text { for crop nutrition, NVZ rules and } \\
\text { recommendations; Technical updates; } \\
\text { Weed/pests/disease identification etc.. }\end{array}$ & NA \\
\hline 34 & UK & Procheck & Pesticide & & & & $\begin{array}{l}\text { Interactive DST consisting of a pesticide } \\
\text { database containing details of product } \\
\text { information updated daily. Allows in-field use; } \\
\text { includes a multi-criteria search engine for } \\
\text { product selection. }\end{array}$ & NA \\
\hline
\end{tabular}


Table A3. Cont.

\begin{tabular}{|c|c|c|c|c|c|c|c|c|}
\hline No. & Country & DST Name & Type of DST ${ }^{1}$ & WQI $^{1}$ & $W^{2}$ & Mitigation $^{3}$ & Brief Description & Reference \\
\hline 35 & UK & SCIMAP & Nutrient & & $\mathrm{Y}$ & & $\begin{array}{l}\text { Helps decision-makers to prioritise activities } \\
\text { that protect the water environment. Generates } \\
\text { probabilistic risk maps for diffuse pollution } \\
\text { from surface pathways within catchments. }\end{array}$ & {$[27]$} \\
\hline 36 & UK & WaterAware & Pesticide & & & & $\begin{array}{l}\text { Phone app estimating risk of selected pesticide } \\
\text { movement based on soil type, soil moisture } \\
\text { deficit and weather conditions. Uses a traffic } \\
\text { light system to advise farmers/sprayer operators } \\
\text { when it is safe to apply chemicals or slug pellets. }\end{array}$ & [62] \\
\hline
\end{tabular}

${ }^{1}$ Represents indicators of water quality such as inputs (use of fertiliser/pesticides), nutrient balance/surplus/efficiency; ${ }^{2}$ Water quality is explicitly represented (e.g., amount or risk of nitrate/pesticide leaching); ${ }^{3}$ Mitigation methods are specifically represented; NA: no published information or website. 


\section{References}

1. Steinebach, Y. Water Quality and the Effectiveness of European Union Policies. Water 2019, 11, 2244. [CrossRef]

2. European Environment Agency. European Waters. Assessment of Status and Pressures 2018. EEA Report 7/2018; Publications Office of the European Union: Luxembourg, 2018.

3. Directorate-General for Agriculture and Rural Development (European Commission). EU Budget: The CAP after 2020; Directorate-General for Agriculture and Rural Development: Brussels, Belgium, 2018. [CrossRef]

4. Erjavec, E.; Jongeneel, R.A.; Garcia Azcárate, T. Research for AGRI Committee-The CAP Strategic Plans beyond 2020: Appraisal of the EC Legislative Proposals; European Parliament, Policy Department for Structural and Cohesion Policies: Brussels, Belgium, 2018.

5. Hogan, P. Common Agricultural Policy Post-2020: Simplification and Modernisation. Speech of Commissioner Phil Hogan at the Agriculture and Fisheries Council on 16 July 2018. Available online: https://ec.europa.eu/info/sites/info/files/food-farming-fisheries/key_policies/presentations/ simplification_modernisation_cap.pdf (accessed on 23 January 2020).

6. Rose, D.C.; Sutherland, W.J.; Parker, C.; Lobley, M.; Winter, M.; Morris, C.; Twining, S.; Ffoulkes, C.; Amono, T.; Dicks, L.V. Decision support tools for agriculture: Towards effective design and delivery. Agric. Syst. 2016, 149, 165-174. [CrossRef]

7. FAIRWAY: Farm Systems Management and Governance for Producing Good Water Quality for Drinking Water Supplies. Available online: https://www.fairway-project.eu/index.php (accessed on 21 January 2010).

8. Drinking Water Inspectorate. Guidance on the Implementation of the Water Supply (Water Quality) Regulations 2000 (as Amended) in England. Version 1.1-March 2012. Available online: http://dwi.defra. gov.uk/stakeholders/guidance-and-codes-of-practice/WS(WQ)-regs-england2010.pdf\#page=18 (accessed on 22 January 2020).

9. Reus, J.A.W.A.; Leendertse, P.C. The environmental yardstick for pesticides: A practical indicator used in the Netherlands. Crop Prot. 2000, 19, 637-641. [CrossRef]

10. FarmHedge. Available online: http://farmhedge.io/ (accessed on 21 January 2020).

11. Bligaard, J. Mark Online, a Full Scale GIS-based Danish Farm Management Information System. Int. J. Food Syst. Dyn. 2014, 5, 190-195.

12. Planteværn Online. Available online: https://plantevaernonline.dlbr.dk//cp/menu/Menu.asp?SubjectID=1\& ID=djf\&MenuID=10009999\&Language=en (accessed on 27 January 2020).

13. Burgt, G.J.H.M.; van der Oomen, G.J.M.; Habets, A.S.J.; Rossing, W.A.H. The NDICEA model, a tool to improve nitrogen use efficiency in cropping systems. Nutr. Cycl. Agroecosyst. 2006, 74, 275-294. [CrossRef]

14. Gibbons, M.M.; Fawcett, C.P.; Waring, R.J.; Dearne, K.; Dampney, P.M.R.; Richardson, S.J. PLANET Nutrient Management Decision Support System—A Standard Approach to Fertiliser Recommendations. In Proceedings of the EFITA/WCCA Conference, Vila Real, Portugal, 25-28 July 2005; pp. 89-94.

15. Nicholson, F.A.; Bhogal, A.; Chadwick, D.; Gill, E.; Gooday, R.D.; Lord, E.; Misselbrook, T.; Rollett, A.J.; Sagoo, E.; Smith, K.A.; et al. An enhanced software tool to support better use of manure nutrients: MANNER-NPK. Soil Use Manag. 2013, 29, 473-484. [CrossRef]

16. AHDB. Nutrient Management Guide (RB209). Available online: https://ahdb.org.uk/RB209 (accessed on 22 January 2020).

17. Nordskog, B.; Rafoss, T.; Nærstad, R.; Hofgaard, I.S.; Hole, H.; Elen, O.; Brodal, G. Farm scale weather data in plant pest forecasting. In Proceedings of the 10th Conference of the European Foundation for Plant Pathology (EFPP), Wageningen, The Netherlands, 1-5 October 2012.

18. SEGES. Dyrkningsvejledninger. Available online: https://dyrk-plant.dlbr.dk/Web/ (S(rtwv44tjpqjr40sgewuih5k3))/forms/Afgroeder.aspx (accessed on 22 January 2020).

19. Sonneveld, M.P.W.; Heuvelink, G.B.M.; Moolenaar, S.W. Application of a visual soil examination and evaluation technique at site and farm level. Soil Use Manag. 2014, 30, 263-271. [CrossRef]

20. Landwirtschaftskammer Niedersachsen. Düngeplanungsprogramm. Available online: https://www.lwkniedersachsen.de/index.cfm/portal/96/nav/2208/article/31583.html (accessed on 22 January 2020).

21. Le Gall, A.-G.; Jouglet, P.; Morot, A.; Guerbet, M. SIRIS-Pesticides: Update and validation of a decision support system for pesticides monitoring in freshwater. In Proceedings of the 17th SETAC Europe Annual Meeting, Porto, Portugal, 20-24 May 2007. 
22. Gooday, R.; Anthony, S.; Chadwick, D.; Newell-Price, P.; Harris, D.; Duethmann, D.; Fish, R.; Collins, A.; Winter, M. Modelling the cost-effectiveness of mitigation methods for multiple pollutants at farm scale. Sci. Total Environ. 2014, 468-469, 1198-1209. [CrossRef]

23. Newell-Price, J.P.; Harris, D.; Taylor, M.; Williams, J.R.; Anthony, S.G.; Duethmann, D.; Gooday, R.D.; Lord, E.I.; Chambers, B.J.; Chadwick, D.R.; et al. An Inventory of Methods and Their Effects on Diffuse Water Pollution, Greenhouse Gas Emissions and Ammonia Emissions from Agriculture. User Guide. Final Report for Defra Project WQ0106 (Module 5). Available online: http://randd.defra.gov.uk/Default.aspx?Menu= Menu\&Module $=$ More $\&$ Location $=$ None\&ProjectID $=14421 \&$ FromSearch $=$ Y\&Publisher $=1 \&$ SearchText $=$ wq0106\&SortString=ProjectCode\&SortOrder=Asc\&Paging=10\#Description (accessed on 24 January 2020).

24. Zhang, Y.; Collins, A.L.; Gooday, R.D. Application of the FARMSCOPER tool for assessing agricultural diffuse pollution mitigation methods across the Hampshire Avon Demonstration Test Catchment, UK. Environ. Sci. Policy 2012, 24, 120-131. [CrossRef]

25. Collins, A.L.; Newell-Price, J.P.; Zhang, Y.; Gooday, R.; Naden, P.S.; Skirvin, D. Assessing the potential impacts of a revised set of on-farm nutrient and sediment 'basic' control measures for reducing agricultural diffuse pollution across England. Sci. Total Environ. 2018, 621, 1499-1511. [CrossRef]

26. Couture, R.M.; Tominaga, K.; Starrfelt, J.; Moe, J.; Kaste, O.; Wright, R.F. Modelling phosphorus loading and algal blooms in a Nordic agricultural catchment-lake system under changing land-use and climate. Environ. Sci. Process. Impacts 2014, 16, 1588-1599. [CrossRef] [PubMed]

27. Perks, M.T.; Warburton, J.; Bracken, L.J.; Reaney, S.M.; Emery, S.B.; Hirst, S. Use of spatially distributed time-integrated sediment sampling networks and distributed fine sediment modelling to inform catchment management. J. Environ. Manag. 2017, 202, 469-478. [CrossRef] [PubMed]

28. Agriwijzer. BedrijfsWaterWijzer. Available online: https://www.agriwijzer.nl/product/17 (accessed on 22 January 2020).

29. Wolf, J.; Beusen, A.H.W.; Groenendijk, P.; Kroon, T.; Rötter, R.; van Zeijts, H. The integrated modeling system STONE for calculating nutrient emissions from agriculture in the Netherlands. Environ. Model. Softw. 2003, 18, 597-617. [CrossRef]

30. dNmark Research Alliance. Fact Sheet: The TargetEconN Framework-A Cost-Minimization Model for Nitrogen Management. Available online: http://dnmark.org/wp-content/uploads/2017/03/Fact-sheetTargetEconN-modelling-framework_Final.pdf (accessed on 22 January 2020).

31. ConTerra. CT-Tools. Available online: http://www.conterra.dk/index.php?action=text_pages_show\&id= $158 \&$ menu=36 (accessed on 25 January 2020).

32. Instituto Nacional de Investigação Agrarian e Veterinaria (INIAV). Manual de Fertilização das Culturas; Laboratório Químico Agrícola Rebelo da Silva: Lisbon, Portugal, 2006.

33. Simões, J.S. Utilização de Produtos Fitofarmaceuticos na Agricultura; Principia: Porto, Portugal, 2005.

34. Kremer, A.M. Methodology and Handbook Eurostat/OECD. Nutrient Budgets. EU-27, Norway, Switzerland. Available online: http://ec.europa.eu/eurostat/cache/metadata/Annexes/aei_pr_gnb_esms_an1. pdf (accessed on 22 January 2020).

35. Andelov, M.; Kunkel, R.; Uhan, J.; Wendland, F. Determination of nitrogen reduction levels necessary to reach groundwater quality targets in Slovenia. J. Environ. Sci. 2014, 26, 1806-1817. [CrossRef]

36. Tetzlaff, B.; Andjelov, M.; Kuhr, P.; Uhan, J.; Wendland, F. Model-based assessment of groundwater recharge in Slovenia. Environ. Earth Sci. 2015, 74, 6177-6192. [CrossRef]

37. Curry, C. A New Era of Targeted Reforestation for Diffuse Pollution Risk Reduction Using SCIMAP and UAV Technology to Determine the Spatial Distribution of Diffuse Pollution Risk in Lake Rawa Pening, Central Java, Indonesia-SCIMAP-UGM16. Available online: http://www.scimap.org.uk/2016/10/a-newera-of-targeted-reforestation-for-diffuse-pollution-risk-reduction-using-scimap-and-uav-technology-todetermine-the-spatial-distribution-of-diffuse-pollution-risk-in-lake-rawa-pening-central-ja/ (accessed on 2 January 2020).

38. Aarts, H.F.M.; de Haan, M.H.A.; Schroder, J.J.; Holster, H.C.; de Boer, J.A.; Reijs, J.; Oenema, J.; Hilhorst, G.J.; Sebek, L.B.; Verhoeven, F.P.M.; et al. Quantifying the environmental performance of individual dairy farms-The Annual Nutrient Cycling Assessment (ANCA). In Proceedings of the 18th Symposium of the European Grassland and Forages in High Output Dairy Farming Systems, Wageningen, The Netherlands, 15-17 June 2015; pp. 377-380. 
39. Department of Environment Food and Rural Affairs (Defra). Use of "Fertiliser Manual (RB209)" Recommendations for Grassland Draft Case Study and Focus Groups Report. Final Report for Defra Project IF01121. Available online: http://sciencesearch.defra.gov.uk/Default.aspx?Menu=Menu\&Module= More\&Location $=$ None\&ProjectID $=17803 \&$ FromSearch $=$ Y\&Publisher $=1 \&$ SearchText $=$ rb209\&SortString= ProjectCode\&SortOrder=Asc\&Paging=10\#Description (accessed on 24 January 2020).

40. Department of Environment Food and Rural Affairs (Defra). The Fertiliser Manual (RB209), 8th ed.; TSO: Norwich, UK, 2015.

41. Axelsen, J.; Munk, L.; Sigsgaard, L.; Ørum, J.E.; Streibig, J.C.; Navntoft, S.; Christensen, T.; Branth, A.; Elkjær, K.; Korsgaard, M.; et al. Udredning om Moniterings, Varslings- og Beslutningsstøttesystemer for Skadevoldere i Planteproduktionen i Landbrug, Gartneri og Frugtavl. Miljøprojekt nr. 1407; Miljøstyrelsen: Odense, Denmark, 2012; Available online: https://www2.mst.dk/Udgiv/publikationer/2012/06/978-87-92779-73-1.pdf (accessed on 24 January 2020).

42. Rose, D.; Parker, C.; Fodey, J.; Park, C.; Sutherland, W.; Dicks, L. Involving Stakeholders in Agricultural Decision Support Systems: Improving User-Centred Design. Int. J. Agric. Manag. 2018, 6, 80-89.

43. Thorling, L.; Ditlefsen, C.; Ernstsen, V.; Hansen, B.; Johnsen, A.R.; Troldborg, L. Grundvandsovervågning. Status og Udvikling 1989-2018. GEUS, 2019. Available online: https://www.geus.dk/media/22654/ grundvand1989-2018-endelig.pdf (accessed on 27 January 2020).

44. Rose, D.C.; Bruce, T.J.A. Finding the right connection: What makes a successful decision support system? Food Energy Secur. 2018, 7, e00123. [CrossRef]

45. Lundström, C.; Lindblom, J. Considering farmers' situated knowledge of using agricultural decision support systems (AgriDSS) to Foster farming practices: The case of CropSAT. Agric. Syst. 2018, 159, 9-20. [CrossRef]

46. Whitman, G.P.; Pain, R.; Milledge, D.G. Going with the flow? Using participatory action research in physical geography. Prog. Phys. Geogr. Earth Environ. 2015, 39, 622-639. [CrossRef]

47. Kudsk, P.; Jørgensen, L.N.; Ørum, J.E. Pesticide Load-A new Danish pesticide risk indicator with multiple applications. Land Use Policy 2018, 70, 384-393. [CrossRef]

48. Inman, D.; Blind, M.; Ribarova, I.; Krause, A.; Roosenschoon, O.; Kassahun, A.; Scholten, H.; Arampatzis, G.; Abrami, G.; McIntosh, B.; et al. Perceived effectiveness of environmental decision support systems in participatory planning: Evidence from small groups of end-users. Environ. Model. Softw. 2011, 26, 302-309. [CrossRef]

49. EIP-AGRI Workshop. Tools for Environmental Farm Performance. Available online: https://ec.europa.eu/eip/ agriculture/sites/agri-eip/files/eip-agri_ws_tools_for_environmental_farm_performance_final_report_2017_en.pdf (accessed on 24 January 2020).

50. WaterProtect. Available online: https://water-protect.eu/ (accessed on 24 January 2020).

51. A New Tool to Increase the Sustainable Use of Nutrients across the EU. Available online: https:/ec.europa.eu/info/ news/new-tool-increase-sustainable-use-nutrients-across-eu-2019-feb-19_en (accessed on 24 January 2020).

52. ISIP—Das Informationssystem für die Integrierte Pflanzenproduktion. Available online: https://www.isip. de/isip/servlet/isip-de (accessed on 24 January 2020).

53. Macary, F.; Morin, S.; Probst, J.-L.; Saudubray, F. A multi-scale method to assess pesticide contamination risks in agricultural watersheds. Ecol. Indic. 2014, 36, 624-639. [CrossRef]

54. Murphy, P. NMP Online. In Proceedings of the Teagasc Soil Fertility Conference, Clonmel, Ireland, 16 October 2015; pp. 8-9.

55. Commissie Bemesting Grasland en Voedergewassen. Bemestingsadvies. Available online: https://edepot. wur.nl/413891 (accessed on 25 January 2020).

56. Everts, H.; Hoving, I.E.; van der Schans, D.A. Beregeningswijzer. Achtergrondinformatie Gebruiksaanwijzing Toelichting vochtboekhouding. Available online: http://edepot.wur.nl/24356 (accessed on 25 January 2020).

57. Skifteplan. Available online: http://www.agromatic.no/skifteplan.html (accessed on 25 January 2020).

58. Mihelič, R.; Čop, J.; Jakše, M.; Štampar, F.; Majer, D.; Tojnko, S.; Vršič, S. SMERNICE Za Strokovno Utemeljeno Gnojenje. Ministrstvo za Kmetijstvo; Gozdarstvo in Prehrano: Ljubljana, Slovenia, 2010; Available online: https://www.program-podezelja.si/sl/knjiznica/26-smernice-za-strokovno-utemeljeno-gnojenje/file (accessed on 25 January 2020).

59. Tehonnik, M.D. Water Quality in Slovenia; Bograf: Ljubljana, Slovenia, 2008. Available online: http: //www.arso.gov.si/en/water/reports\%20and\%20publications (accessed on 25 January 2020). 
60. Fito-Info: Slovenian Information System for Plant Protection. Available online: http://www.fito-info.si/E_ index.asp (accessed on 25 January 2020).

61. Check it Out Tool. Available online: http://checkitout.voluntaryinitiative.org.uk/tool/ (accessed on 25 January 2020).

62. WaterAware App. Available online: http://www.adama.com/uk/en/wateraware/ (accessed on 25 January 2020).

(C) 2020 by the authors. Licensee MDPI, Basel, Switzerland. This article is an open access article distributed under the terms and conditions of the Creative Commons Attribution (CC BY) license (http://creativecommons.org/licenses/by/4.0/). 